\title{
GIS-based Spatio-Temporal and Geostatistical Analysis of Groundwater Parameters of Lahore Region Pakistan and their Source Characterization
}

\author{
Sadia Ismail ( $\square$ sadiaismail@uet.edu.pk) \\ University of Engineering and Technology \\ M Farooq Ahmed \\ UET: University of Engineering \&amp; Technology
}

\section{Research Article}

Keywords: groundwater, EWQI, GIS, spatio-temporal, geostatistics

Posted Date: April 22nd, 2021

DOl: https://doi.org/10.21203/rs.3.rs-431857/v1

License: (c) (1) This work is licensed under a Creative Commons Attribution 4.0 International License.

Read Full License 
1 GIS-based spatio-temporal and Geostatistical Analysis of Groundwater Parameters of Lahore Region

2 Pakistan and their Source Characterization

3 Sadia Ismail ${ }^{1}$ and M. Farooq Ahmed ${ }^{1}$

$4{ }^{1}$ Department of Geological Engineering, University of Engineering and Technology, G.T. Road, Lahore 54890,

5 Pakistan, +923004003099, sadiaismail@uet.edu.pk

6

$7 \quad{ }^{1}$ Department of Geological Engineering, University of Engineering and Technology, G.T. Road, Lahore 54890,

8 Pakistan, +923346435070, mfageo@uet.edu.pk

9

10 Declaration

11 Funding: This research work was partially funded by the University of Engineering and Technology, Lahore,

12 Pakistan.

13 Availability of data and material: The authors have no reservations about sharing the data and material used for this 14 study upon request.

15 Code availability: No new codes were generated for this study.

16 Authors' contributions: The corresponding author Ms. Sadia Ismail is a PhD scholar and main contributor to this

17 research work. The second author, Mr. Muhammad Farooq Ahmad, is her PhD research supervisor.

18 Ethics approval: This article does not include any material that is already published elsewhere so no any formal 19 approval is required for the material used in this article. This is the authors' original work and found $8 \%$ plagiarism as

20 Turnitin before the submission, which is within allowable limits.

21 Consent to participate: NA

22 Consent for publication: Closed access publication

23 Conflicts of interest

24 The authors do not have any conflict of interest.

25

26

27

28

29

30

31 


\section{ABSTRACT}

Assessment of groundwater quality is critical, especially in the areas where it is continuously deteriorating due to unplanned industrial growth. This study utilizes GIS-based spatio-temporal and geostatistics tools to characterize the groundwater quality parameters of Lahore region. For this purpose, a large data set of the groundwater quality parameters (for a period of 2005-2016) was obtained from the deep unconfined aquifers. GIS-based water quality index (WQI) and entropy water quality index (EWQI) models were prepared using 15 water quality parameters $\mathrm{pH}$ (power of hydrogen), TDS (Total dissolve solids), EC (Electrical conductivity), TH (Total hardness), $\mathrm{Ca}^{2+}$ (Calcium), $\mathrm{Mg}^{2+}$ (Magnesium), $\mathrm{Na}^{+}$(Sodium), $\mathrm{K}^{+}$(Potassium), $\mathrm{Cl}^{-}$(Chloride), As (Arsenic), $\mathrm{F}$ (Fluoride), $\mathrm{Fe}$ (Iron), $\mathrm{HCO}_{3}^{-}$ (Bicarbonate), $\mathrm{NO}_{3}{ }^{-}$(Nitrate), and $\mathrm{SO}_{4}{ }^{2-}$ (Sulfate). The data analysis exhibits that $12 \%$ of the groundwater samples fell within the category of poor quality that helped to identify the permanent epicenters of deteriorating water quality index in the study area. As per the entropy theory, $\mathrm{Fe}, \mathrm{NO}_{3}{ }^{-}, \mathrm{K}, \mathrm{F}, \mathrm{SO}_{4}{ }^{2-}$ and $\mathrm{As}$, are the major physicochemical parameters those influence groundwater quality. The spatio-temporal analysis of the large data set revealed an extreme behavior in $\mathrm{pH}$ values along the Hudiara drain, and overall high arsenic concentration levels in most of the study area. The geochemical analysis shows that the groundwater chemistry is strongly influence by subsurface soil water interaction. The research highlights the significance of using GIS-based spatio-temporal and geostatistical tools to analyze the large data sets of physicochemical parameters at regional level for the detailed source characterization studies.

Key Words: groundwater, EWQI, GIS, spatio-temporal, geostatistics

\section{INTRODUCTION}

Water is an essential component of the hydrologic cycle, which travels in many different forms like evaporation, evapotranspiration, precipitation, and finally, as runoff on the earth's surface. This valuable natural resource is essential for life and the environment (Fetter 2013). Groundwater is the primary resource everywhere globally for irrigation, domestic and drinking purposes, and its quality preservation is the need of the day. Overexploitation and excessive groundwater withdrawal result in a gradual decrease in water table levels. The erratic supply of water has created water shortages all over the world.

Groundwater contamination is a critical problem almost everywhere in the world (Hudak 2000; Sadat-Noori et al. 2014; Tiwari et al. 2017). Its quality is adversely affected by the number of anthropogenic activities like demographic migration, urbanization, industrialization, over pumping and excessive use of fertilizers and in the same way by geogenic activities, amount and quality of atmospheric precipitation, underground hydro-geochemical processes, and origin and quality of recharge water (Vasanthavigar et al. 2010; Tiwari et al. 2018). Appropriate methodologies should be adopted to eliminate water scarcity and assess the new water potential zones (Ketata et al. 2012; Pazand 2016). Presently aquifer water is the primary source of potable water in Pakistan's major cities. Most of the groundwater reserves got contaminated because of the disposing of untreated municipal, commercial, residential, and industrial waste directly into the nearby streams, channels, drains, ponds, rivers, and open fields or agricultural lands (Azizullah et al. 2011; Qureshi and Sayed 2014). This untreated industrial effluent waste contains many metals and metal ions contaminating the groundwater and soil, hazardous for humans and other living things (Qureshi and 
Sayed 2014). Just $20 \%$ of Pakistan's population uses safe drinking water, and the rest is compelled to utilize untreated contaminated water. Sewerage contamination in freshwater sources must be considered a critical ecological and medical concern (Azizullah et al. 2011).

At present, several techniques have been applied to groundwater characterization and quality assessment. Fuzzy mathematical method (Kamrani et al. 2016), Cluster analysis (Hosseinimarandi et al. 2014), set of pair analysis techniques (Pei-Yue et al. 2011), and blind number approach (Yan and Zou 2014) are one of them. However, these techniques cannot be easily applied at a regional scale by incorporating many factors for groundwater characterization. Modern tools and more innovative ways are essential to study spatial and temporal studies on a regional level to understand and identify the natural and anthropogenic contamination sources. Geographic Information System (GIS) has gained significant importance in different earth sciences, including geological sciences and engineering, geomorphology, environment, groundwater and surface water contamination, waste disposal and landfill site selection studies, climate changes, and environmental sciences. Most researchers concluded that the GIS is a useful and effective tool for organizing physicochemical databases. It has a broad application in detection, monitoring, assessment, and modeling the spatio-temporal variation for the surface and subsurface water resource evaluation and characterization (Strassberg 2005; Faunt and Ed. 2009; Ketata et al. 2012; Sadat-Noori et al. 2014; Thapa et al. 2017). A number of studies are successfully performed to model the water quality in a GIS environment by considering the spatial distribution of physicochemical parameters, like the GIS-based inverse distance weighted (IDW) method (Tiwari et al. 2017), water quality index (Charizopoulos et al. 2018), entropy water quality index (Gorgij et al. 2017), and advanced statistical tools (Sadat-Noori et al. 2014; Pazand 2016; Chaurasia et al. 2018).

The regional level groundwater characterization studies (i.e., with a large amount of data set) must be conducted by applying more robust, quick, and reliable spatio-temporal analysis tools. GIS-based water quality index method is widely utilized to assess the quality parameters of surface and groundwater resources (Al-hadithi 2012; Ketata et al. 2012; Sadat-Noori et al. 2014; Shabbir and Ahmad 2015). Water quality index (WQI) is a rating approach that assists in studying the overall quality of water by considering individual physicochemical parameters. Initially, Horton introduced the Water quality index (WQI) concept that often consists of water quality parameters. Later on, it was updated by Brown and Deininger for the Scottish Development Department (Sadat-Noori et al. 2014). The most crucial component of healthy water parameters that should be incorporated in preparing water quality index maps includes; $\mathrm{pH}, \mathrm{TDS}, \mathrm{Ca}^{2+}, \mathrm{Mg}^{2+}, \mathrm{Na}^{+}, \mathrm{K}^{+}, \mathrm{Cl}^{-}$, and $\mathrm{SO}_{4}{ }^{2-}$ (Saeedi et al. 2010). Later on, numerous researchers found this index useful to evaluate the groundwater quality based on different physicochemical parameters (Ketata et al. 2012; Sadat-Noori et al. 2014; Islam et al. 2017; Tiwari et al. 2018).

Multivariate statistical analysis is a widely used approach among the several other methods to identify the potential contamination sources and possible factors affecting water quality in different parts of the world (El Alfy 2010; Okiongbo and Douglas 2015; Pazand 2016; Islam et al. 2017). It is a useful tool to evaluate the complex water quality parameters and identify the main anthropogenic activities and potential contamination sources affecting aquifer resources. Physicochemical parameter having a significant correlation coefficient, indicating similar source of origination, which could be geogenic (weathering and disintegration of soil-forming minerals), or anthropogenic (Okiongbo and Douglas 2015; Pazand 2016). The chemical composition of the groundwater could be assessed by the 
of processes in the groundwater aquifer systems ( Al-Ahmadi 2013; Pazand 2016; Selvam et al. 2016; Tiwari et al. 2017).

The current study aims to provide a holistic view of the groundwater source characterization using modern tools, including GIS-based geostatistical techniques, WQI, EWQI, and multivariate statistics. This study will help to

111 identify the major contributing factors (either anthropogenic or geogenic) to groundwater contamination at the regional

112 scale. Previously for this region, a few scattered studies were performed by incorporating small data sets to identify

113 and evaluate the surface contamination zones using conventional statistical methods and simple GIS techniques, 114 including WQI, buffering, and Kriging on a limited scale. This study deals with the considerable amount of 115 physicochemical parameters data acquired in several years (2005-2016) of hundreds of water wells with different 116 depths (mostly deep wells). This research evaluates and identifies potential groundwater contamination sources and prepares a groundwater quality map based on the water quality index and entropy water quality index. The study outcome could help in understanding the spatio-temporal deviations in groundwater quality and understand the local authorities' primary groundwater contamination sources and their characterization.

\section{STUDY AREA}

Lahore city is the capital of Punjab Province of Pakistan, covering a total area of $1,772 \mathrm{~km}^{2}$. It has a flat surface with a variation of altitude from 208 to 213 meters above MSL. Lahore's population has recently crossed the mark of 10 million and is considered in the world's most populated areas (Qureshi and Sayed 2014). The study area's climate can be classified as semi-arid with long and intensely hot summers. The mean annual rainfall of Lahore is 680 $\mathrm{mm}$, with heavy down pouring that usually occurs during the monsoon season, providing $40 \%$ of the total groundwater recharge (Mahmood et al. 2016). The Lahore's unconfined aquifer is composed of unconsolidated alluvial deposits up to $400 \mathrm{~m}$ thickness with a transmission rate of about $2,100 \mathrm{~m}^{2} /$ day and alternate layers of sand, silt, and clay formations (Farooqi et al. 2007; Qureshi and Sayed 2014). The groundwater is the significant source for drinking, domestic and industrial usage in the area under study. The $82 \%$ of the groundwater aquifer of Lahore is recharged by River Ravi (the primary source), $12 \%$ from monsoon rainfall, and $6 \%$ from the return flows from irrigation (Qureshi and Sayed 2014).

Table 1 Zones of the Lahore by Local Government, Punjab

\begin{tabular}{ccc}
\hline Sr \# & Directions & Zones of Lahore \\
\hline 1 & North & Ravi, Shalimar and Data Gunj Baksh zone \\
2 & South & Nishter zone \\
3 & East & Wagha zone \\
4 & West & Iqbal zone \\
5 & Central Part & Aziz Bhatti and Gulberg zone \\
6 & Northwest & Samanabad zone \\
\hline
\end{tabular}




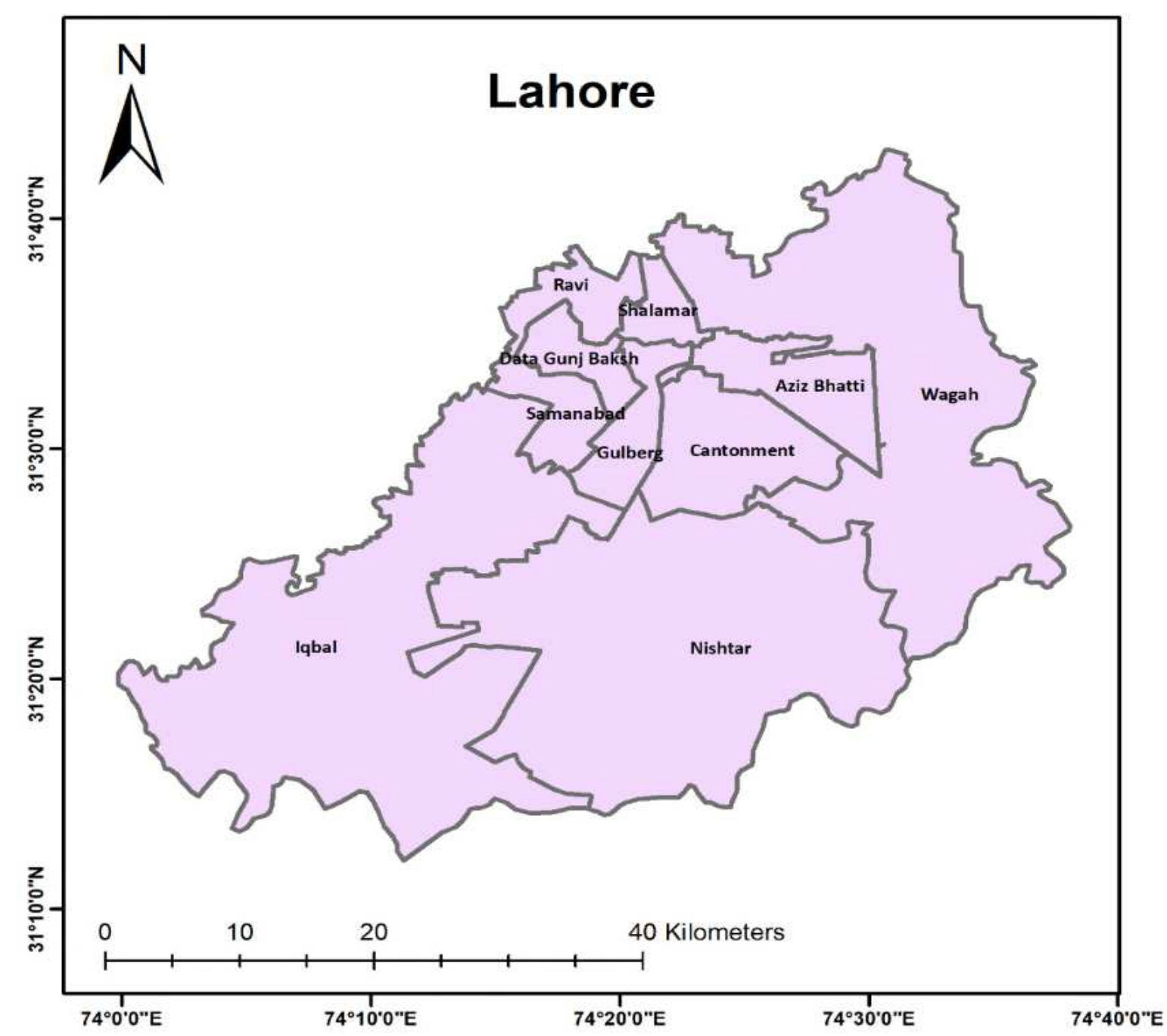

Fig.1 Zonal Classification of the study area

Water is supplied by the Water and Sanitation Agency (WASA) in more than 150 union councils of Lahore. Till the year 2009, WASA installed approximately 380 pumping wells to meet the local population requirements of water. Afterward, 200 more wells were added to the system by considering the increasing water demand due to the rapid growth in industrial and population (Qureshi and Sayed 2014). Lahore is a larger metropolitan city, accordingly for this study, a map with the City Districts boundaries, Towns/Tehsil, and Union Councils levels were used to show the trends of spatio-temporal variations in the groundwater quality for convenience (The Local Government Ordinance in 2001, Administrative bodies for Districts). (see Table $1 \&$ Fig. 1)

\section{DATA AND METHODS}

Data of 1305 valid sampling points were collected from different departments of Lahore (see Fig. 2) from 2005 to 2016. During this period, acid washed high density polyethylene (HDPE) bottles were used to collect water samples as per the standard procedure. Global Positioning System (GPS) was used to record the geographic 
coordinates of each sampling location. These collected water samples were analyzed to measure the hydrochemical parameters' concentration using the American Public Health Association (APHA 1995). This yearly examined groundwater quality parametric data such as $\mathrm{pH}$, TDS, $\mathrm{EC}, \mathrm{TH}, \mathrm{Ca}^{2+}, \mathrm{Mg}^{2+}, \mathrm{Na}^{+}, \mathrm{K}^{+}, \mathrm{Cl}+\mathrm{As}, \mathrm{F}, \mathrm{Fe}, \mathrm{HCO}_{3}{ }^{-}, \mathrm{NO}_{3}{ }^{-}$, and $\mathrm{SO}_{4}{ }^{2-}$ for the period 2005-2016 has been acquired from these departments including Pakistan Council of Research in Water Resource (PCRWR), Public Health Engineering Department and NESPAK, Lahore.

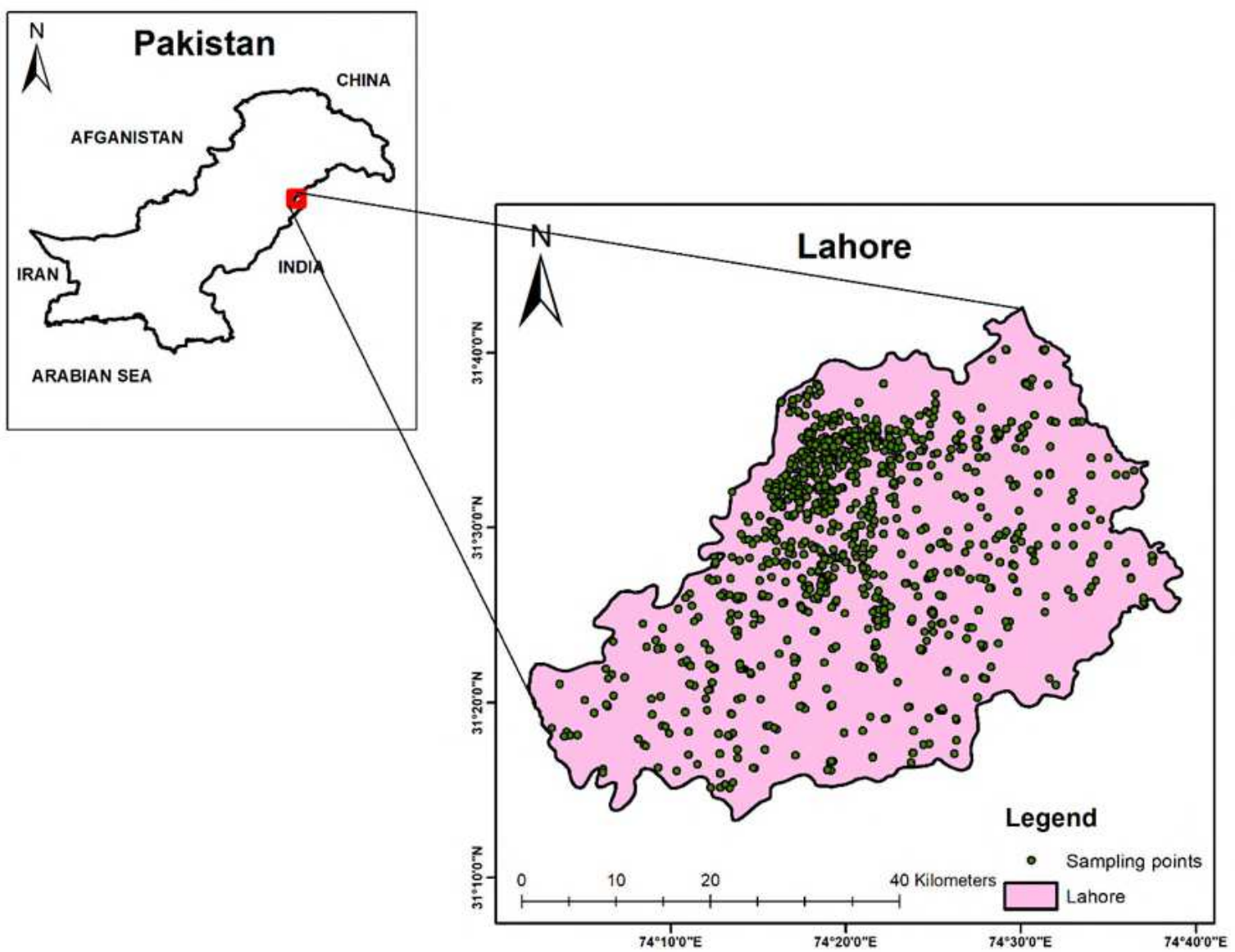

Fig. 2 Location of groundwater sampling points in the study area

For the verification of the data's precision, the analyses were carried out for Cation and anion ionic charge balances $(<10 \%)$, results more significant than $10 \%$ were not accepted (Islam et al. 2017). The expression used for the calculation of ionic charge balance is written as follows:

$$
\operatorname{ICBE}(\%)=\left(\frac{\sum \text { Cations }-\sum \text { Anions }}{\sum \text { Cations }+\sum \text { Anions }}\right) \times 100 \ldots(1)
$$

ArcGIS 10.7 software was used for this study, a valuable tool for organizing a physicochemical database (Sadat-Noori et al. 2014; Shabbir and Ahmad 2015; Thapa et al. 2017). GIS is a preferred option to present the sampling data geographically as a shape file and prepare Spatial-temporal distribution maps to assess groundwater quality change. GIS-based Interpolation techniques have been utilized to deal with the data with a continuous distribution of variables that estimate the parameter value at unsampled locations (Muhammad and Zhonghua 2014; Gong et al. 2014; Charizopoulos et al. 2018). Different types of Kriging interpolation models used different 
mechanisms of prediction, such as indicator, ordinary, universal, Inverse distance weighted (IDW), and simple Kriging. All the aforementioned interpolation methods had been practiced for each physicochemical parameter. With the help of cross-validation criteria, the best-optimized approach of Inverse distance weighted (IDW) was used to prepare the spatio-temporal maps of each quality parameter.

IDW is generally suitable for the studies where spatial continuity is required to determine through interpolation (Balakrishnan 2011; Ketata et al. 2012; Selvam et al. 2016; Charizopoulos et al. 2018; Bairu et al. 2020). Interpolated data shows variation spatially to estimated and measured data points and creates different thematic layers for each ion (Selvam et al. 2016). These IDW assessed values are the weighted average values of the surrounding sample locations (Magesh et al. 2011; Selvam et al. 2016) and can be improved by using a power function, mostly with its default value 2 , whereas some other optimized values are also used for better results. The time series analysis was performed after developing precise interpolated (IDW) surfaces on the same spatial scale for the quality parameters of $\mathrm{pH}$, TDS, $\mathrm{EC}, \mathrm{TH}, \mathrm{Ca}^{2+}, \mathrm{Mg}^{2+}, \mathrm{Na}^{+}, \mathrm{K}^{+}, \mathrm{Cl}^{-}$, As, $\mathrm{F}, \mathrm{Fe}, \mathrm{HCO}_{3}{ }^{-}, \mathrm{NO}_{3}{ }^{-}$, and $\mathrm{SO}_{4}{ }^{2-}$. The multivariate statistical technique (principal component analysis) was run using the statistical package for social sciences (SPSS version 22.0) software for the computation of experimental groundwater data. The relationship between the pairs of different physicochemical can be identified with the help of a correlation matrix. Identification of hydrogeochemical processes has been computed using the Grapher software (version 16.1) for groundwater classification, resulting in variations in groundwater composition.

\section{Water Quality Index}

The water quality index is the best way to summarize drinking water quality. It is used to identify the areas with suitable water for drinking purposes. WQI method was applied in the GIS environment on the available groundwater quality data of different years (i.e., 2005-2016). The WQI was calculated through three steps. In the first step a weight $\left(\mathrm{w}_{\mathrm{i}}\right)$ has been allocated to 15 quality parameter $\mathrm{pH}$, TDS, $\mathrm{EC}, \mathrm{TH}, \mathrm{Ca}^{2+}, \mathrm{Mg}^{2+}, \mathrm{Na}^{+}, \mathrm{K}^{+}, \mathrm{Cl}^{-}, \mathrm{As}, \mathrm{F}, \mathrm{Fe}$, $\mathrm{HCO}_{3}{ }^{-}, \mathrm{NO}_{3}{ }^{-}$, and $\mathrm{SO}_{4}{ }^{2-}$ as per their perceived significance in the drinking water quality. The parameters such as EC, TDS, $\mathrm{Cl}^{-}, \mathrm{NO}_{3}{ }^{-}, \mathrm{Na}^{+}, \mathrm{F}, \mathrm{As}$, and $\mathrm{SO}_{4}{ }^{2-}$ have been allocated a maximum weight of 5 considering their significant importance in drinking water quality (Srinivasamoorthy et al. 2008; Vasanthavigar et al. 2010; Thapa et al. 2017; Tiwari et al. 2018). The minimum weight of 1 has been given to $\mathrm{HCO}_{3}{ }^{-}$in water quality assessment due to its insignificant role. The remaining quality parameters $\left(\mathrm{pH}, \mathrm{TH}, \mathrm{Ca}^{2+}, \mathrm{Mg}^{2+}, \mathrm{K}^{+}\right.$, and $\mathrm{Fe}$ ) have been assigned a weight between 1 and 5 (Ketata et al. 2012; Sadat-Noori et al. 2014). Each physicochemical parameter's relative weight ( $\mathrm{W}_{\mathrm{i}}$ ) is calculated in the second step with the help of the following Eq. (2):

$$
W_{i}=\left(w_{i}\right) / \sum_{i=1}^{n} w_{i}
$$

Each physicochemical parameter's input weight is represented by $\left(\mathrm{w}_{\mathrm{i}}\right)$, total number of quality parameters is represented by $\mathrm{n}$, and $\mathrm{W}_{\mathrm{i}}$ is the ith parameter's relative weight. In the third step, a quality rating scale (qi) is calculated by using the following Eq. (3):

$$
q_{i}=\left(\frac{C_{i}}{S_{i}}\right) \times 100
$$


It is computed by dividing each water sample concentration to its own standard (WHO 2004) and multiplying by 100. The quality ranking is represented by qi, $\mathrm{Ci}$ is the measured concentration of each physicochemical parameter, and $\mathrm{Si}$ is the WHO standard value for the same parameter in $\mathrm{mg} / \mathrm{l}$. Finally, for the calculation of WQI, the sub-index $\left(\mathrm{SI}_{\mathrm{i}}\right)$ of the ith parameter is first determined by using the following Eq. (4). Finally, Eq. (5) is utilized to calculate the WQI.

$$
\begin{gathered}
S l_{i}=\left(W_{i} \times q_{i}\right) \\
W Q I=\sum_{i=1}^{n} S l_{i}
\end{gathered}
$$

\section{Entropy Water Quality Index}

The theory of entropy has been applied in various fields of hydrology and water quality assessment studies. Shannon Claude was the first to propose the concept of information entropy in 1948 (Pei-Yue et al. 2010). Mathematically, it reports the degree of uncertainty and expresses an event's randomness (Shyu et al. 2011). A negative correlation exists between entropy weight and the amount of information entropy. The entropy weight value will be great if the Shannon entropy will be small (Amiri et al. 2014; Islam et al. 2017; Gorgij et al. 2017). The justification for using this method is to state the significance of physicochemical parameters in terms of entropy weight. In this research, the entropy method can also accurately characterize groundwater quality parameters, and EWQI can be calculated using the following steps (Pei-Yue et al. 2010; Islam et al. 2017). In the first step, eigenvalue matrix X can be constructed as follows in Eq. (6) by using the "m" number of groundwater samples ( $\mathrm{i}=1,2,3, \ldots \ldots ., \mathrm{m})$ taken from the research area and $n "$ number of quality parameters $(j=1,2,3, \ldots \ldots, n)$.

$$
\mathbf{X}=\left|\begin{array}{cccccc}
\mathrm{x}_{11} & \mathrm{x}_{12} & \mathrm{x}_{13} & \cdot & \cdot & \mathrm{x}_{1 \mathrm{n}} \\
\mathrm{x}_{21} & \mathrm{x}_{22} & \mathrm{x}_{23} & \cdot & \cdot & \mathrm{x}_{2 \mathrm{n}} \\
\cdot & \cdot & \cdot & \cdot & \cdot & \cdot \\
\cdot & \cdot & \cdot & \cdot & \cdot & \cdot \\
\mathrm{x}_{\mathrm{m} 1} & \mathrm{x}_{\mathrm{m} 2} & \mathrm{x}_{\mathrm{m} 3} & \cdot & \cdot & \mathrm{x}_{\mathrm{mn}}
\end{array}\right|
$$

The normalizing function is applied to eliminate the effect of different units of physicochemical parameters and converted to matrix Y, defined in Eq. (7)

$$
\mathbf{Y}=\left|\begin{array}{cccccc}
Y_{11} & \mathrm{Y}_{12} & Y_{13} & \cdot & \cdot & Y_{1 \mathrm{n}} \\
\mathrm{Y}_{21} & \mathrm{Y}_{22} & \mathrm{Y}_{23} & \cdot & \cdot & \mathrm{Y}_{2 \mathrm{n}} \\
\cdot & \cdot & \cdot & \cdot & \cdot & \cdot \\
\cdot & \cdot & \cdot & \cdot & \cdot & \cdot \\
\mathrm{Y}_{\mathrm{m} 1} & \mathrm{Y}_{\mathrm{m} 2} & \mathrm{Y}_{\mathrm{m} 3} & \cdot & \cdot & Y_{\mathrm{mn}}
\end{array}\right| \ldots \ldots \ldots \ldots \ldots(7)
$$

The parameter index value for all groundwater samples is subsequently calculated using Eq. (8).

$$
P_{i j}=\left(Y_{i j}\right) / \sum_{i=1}^{m}\left(Y_{i j}\right)
$$

The entropy (ej) can be computed, using Eq. (9) used for all parameters.

$$
e_{j}=\frac{1}{\ln m} \sum_{i=1}^{m} P_{i j} \ln P_{i j}
$$

Then the entropy weight $\left(\mathrm{w}_{\mathrm{j}}\right)$, can be calculated for each parameter using the following Eq. (10). 


$$
w_{j}=\frac{1-e_{j}}{\sum_{j=1}^{n}\left(1-e_{j}\right)}
$$

A qualitative grade $\left(\mathrm{q}_{\mathrm{j}}\right)$ is computed for each groundwater quality parameter using Eq. (11).

$$
q_{i}=\frac{C_{j}}{S_{j}} \times 100
$$

$\mathrm{Cj}$ represents all physicochemical parameters' concentration, and $\mathrm{S}_{\mathrm{j}}$ is the permissible limit according to WHO standards. The entropy water quality index (EWQI) is computed using the following Eq. (12).

$$
E W Q I=\sum_{j=1}^{n}\left(w_{j} q_{j}\right)
$$

Spatial disparity maps of WQI and EWQI from 2005 to 2016 were prepared to recognize the regions with poor groundwater quality. For a convenient comparison, all-time series data related to WQI and EWQI were categorized into five classes, presented in Table 2. (Vasanthavigar et al. 2010; Jianhua et al. 2011; Tiwari et al. 2018).

Table 2 Range of WQI (Tiwari et al. 2018), EWQI (Jianhua et al. 2011), and quality of water

\begin{tabular}{cccc}
\hline $\begin{array}{c}\text { WQI } \\
\text { Range }\end{array}$ & Quality of water & $\begin{array}{c}\text { EWQI } \\
\text { Range }\end{array}$ & Quality of water \\
\hline$<50$ & Excellent & $<50$ & Excellent \\
$50-100$ & Good & $50-100$ & Good \\
$100-200$ & Poor & $100-150$ & Medium \\
$200-300$ & Very poor & $150-200$ & Poor \\
$>300$ & $\begin{array}{c}\text { Not fit for } \\
\text { drinking }\end{array}$ & $>200$ & Extremely poor \\
& & & \\
\hline
\end{tabular}

\section{RESULTS AND DISCUSSION}

Groundwater quality variation can be best interpreted by using spatial-temporal maps of different physicochemical parameters. This study has resulted in a comprehensive analysis of selected parameters $\mathrm{pH}$, TDS, EC, TH, $\mathrm{Ca}^{2+}, \mathrm{Mg}^{2+}, \mathrm{Na}^{+}, \mathrm{K}^{+}, \mathrm{Cl}^{-}, \mathrm{As}, \mathrm{F}, \mathrm{Fe}, \mathrm{HCO}_{3}{ }^{-}, \mathrm{NO}_{3}{ }^{-}$, and $\mathrm{SO}_{4}{ }^{2-}$ that have a maximum impact on Groundwater quality. Initially, the ionic charge balance was computed to verify the complete chemical analysis accuracy between the cations $\left(\mathrm{Ca}^{2+}, \mathrm{Mg}^{2+}, \mathrm{Na}^{+}\right.$, and $\left.\mathrm{K}^{+}\right)$and anions $\left(\mathrm{HCO}_{3}{ }^{-}, \mathrm{Cl}^{-}, \mathrm{SO}_{4}{ }^{2-}\right.$ and $\left.\mathrm{NO}_{3}{ }^{-}\right)$. It was observed that approximately $96 \%$ of the water samples were within this range of $<10 \%$. The measured relative standard deviation for all collected groundwater samples is within the range of $\pm 2 \%$.

\section{Spatio-Temporal Analysis of Individual Physicochemical Parameters}

Spatio-temporal thematic maps of all the quality parameters were prepared by utilizing the best fit interpolation technique IDW. By considering the correlation matrix and \% of the samples exceeding allowable limits prescribed by WHO standards, the maps of $\mathrm{Ca}^{2+}, \mathrm{Mg}^{2+}, \mathrm{Cl}^{-}, \mathrm{Fe}, \mathrm{NO}_{3}{ }^{-}$and $\mathrm{F}$ were not shown here because all samples lie within the permissible limit. In this research, fifteen quality parameters were characterized into classes as per their minimum and maximum values to understand their possible trends considering WHO Standards. Finally, to show the 
data's spatial and temporal variation, thematic maps of all the quality parameters were created for further analysis for the study area.

\section{pH}

A relatively high percentage of 56\% of samples in the year 2005 was observed to have $\mathrm{pH}$ values exceeding the prescribed limit of WHO guideline values for drinking water. Only a few samples showed a neutral pH value, and all of the other samples had high $\mathrm{pH}$ values.
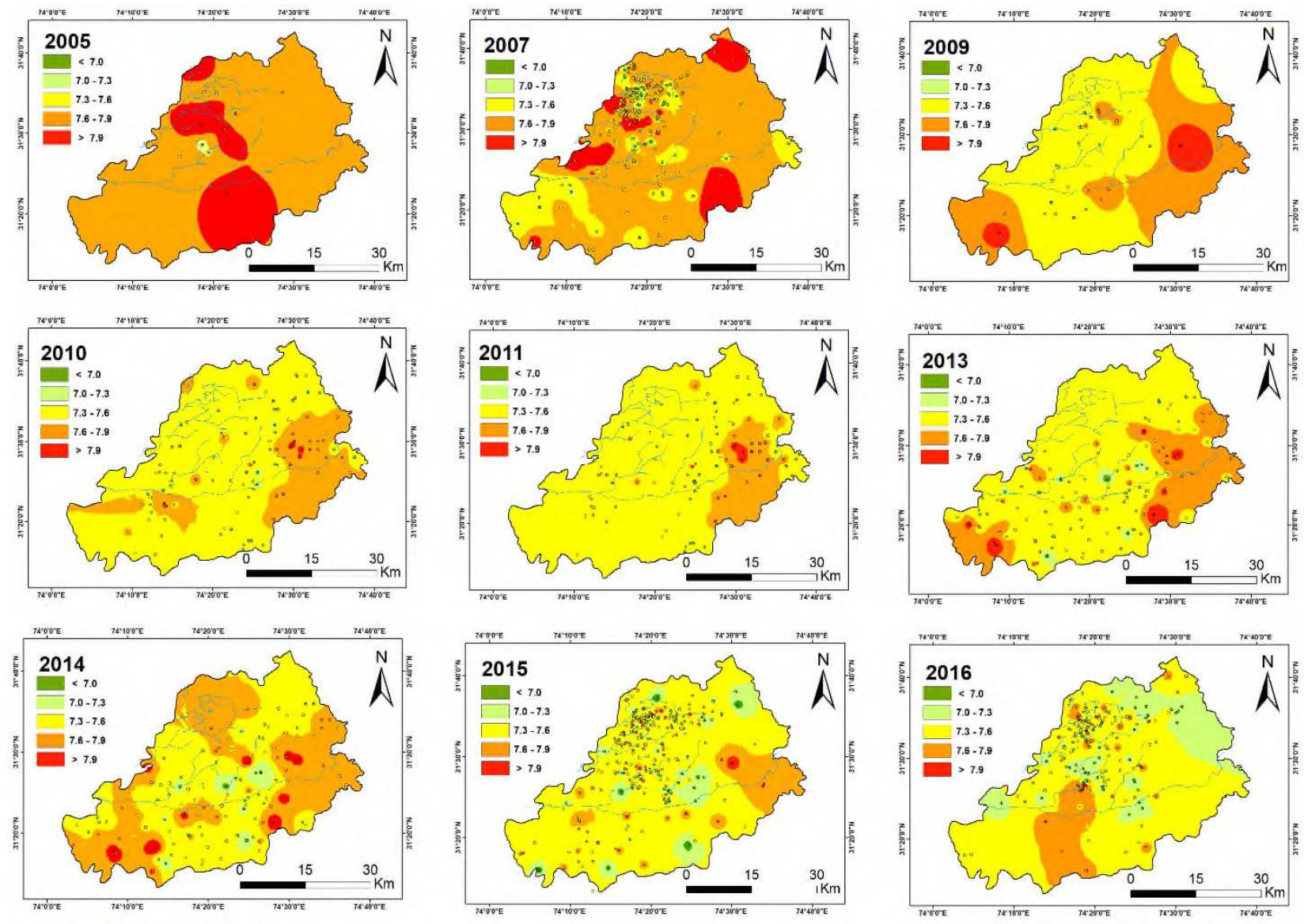

Fig. 3 Spatio-Temporal map of $\mathrm{pH}$ in the Lahore region

Spatio-Temporal maps, as shown in Fig. 3, suggest that the area along the Hudiara drain (Wagah, Nishter and Iqbal zone) falls above the neutral value indicating the alkaline behavior of water. Hudiara drain originates from Batala (Punjab, India), and in Amritsar, after joining many tributaries, enters Pakistan near village Laloo (Yaseen et al. 2009). It flows through the border area between Pakistan and India, so domestic wastewater and industrial effluents are being discharged from both sides into this drain without treatment. Many industries, including textile mills, paper, electronic, plastic, paint, and pharmaceutical industries, are the primary source of pollution, which are the reasons for a cautious increase in pH value along the Hudiara Drain (Afzal et al. 2000). Overall, it is clear from the maps generated for this study that there is no significant $\mathrm{pH}$ value change. However, all Lahore zones in different periods showed higher values (more than 7.99), with a maximum of 8.5 except for very few Lahore areas. The peak value of $\mathrm{pH}$ of 
8.9 was observed in the Samanabad zone of Lahore. After the year 2007, a decreasing trend had been identified in $\mathrm{pH}$ values with a maximum value of 8.5 in 2013 Wagha Town, Lahore. A high concentration plume reappeared in 2014 in the Southwestern part of Lahore with a peak value of 8.7. In comparison with other years in 2015 and 2016, an increase in $\mathrm{pH}$ values spread. The region along the Hudiara drain remained prominent with a progressive $\mathrm{pH}$ concentration in the temporal analysis.

\section{Total Dissolved Solids (TDS)}

The analysis shows a relatively high percentage ( $25 \%$ to $84 \%$ ) of the samples having TDS values of more than $500 \mathrm{mg} / \mathrm{l}$. Spatio-temporal distribution of TDS is demonstrated in Fig. 4.
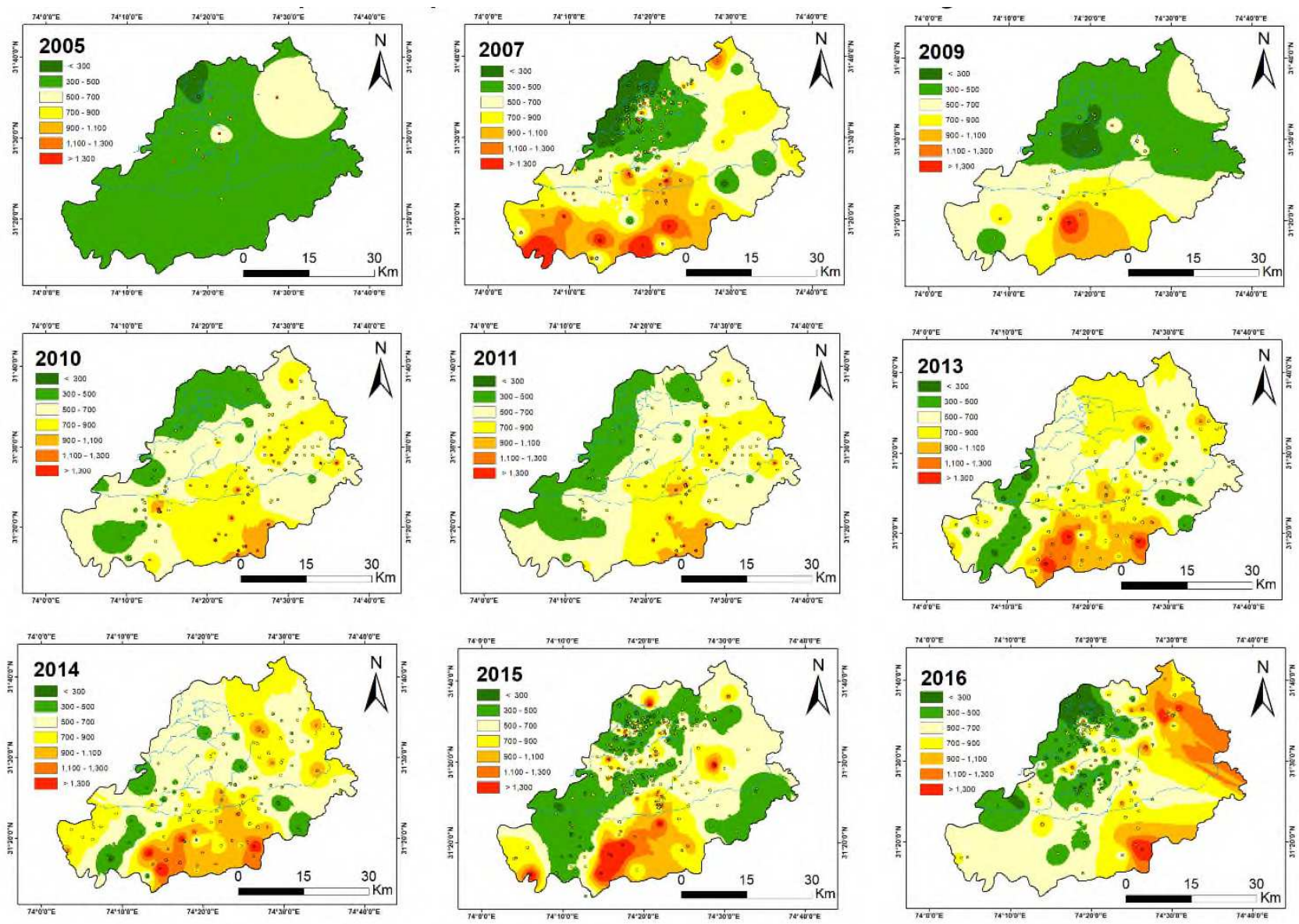

Fig. 4 Spatio-Temporal map of TDS in the Lahore region

The present study shows a remarkable change in TDS concentration with the lowest value of $762 \mathrm{mg} / \mathrm{l}$ in 2005, and an increasing trend has been observed in the peak value of $2182 \mathrm{mg} / \mathrm{l}$ and $1875 \mathrm{mg} / \mathrm{l}$ in the years 2007 and 2009, respectively. In the years 2010 and 2011, a small reduction in TDS value was observed, then its value goes up to $2710 \mathrm{mg} / \mathrm{l}$ in the region. The most southern part (Nishter town) of the Lahore area, including few villages, exhibits TDS' highest values. In short, the spatio-temporal maps reveals that most of the research area under study showed the TDS value $>500 \mathrm{mg} / \mathrm{l}$ for all the years under consideration, hence making it unsuitable for drinking purposes. Based on this analysis, only a few Lahore areas meet WHO standards, which is quite alarming for the local authorities. 
Anthropogenic activities like urban, agricultural, industrial, and sewage wastewater could be the primary sources of TDS in groundwater. Geogenic processes are also responsible for the high concentration of TDS in groundwater due to the mixing of $\mathrm{Ca}^{2+}, \mathrm{HCO}_{3}{ }^{-}, \mathrm{Cl}^{-}$, and $\mathrm{SO}_{4}{ }^{2-}$ (Subba Rao 2002; Muhammad and Zhonghua 2014; Mahmood et al. 2016).

\section{Electrical Conductivity (EC)}

The electrical conductivity (EC) of groundwater could be due to numerous dissolved salts. Around $16 \%$ of the samples (see Table 3) were found to have electrical conductivity values exceeding the WHO recommended standards. Fig. 5 shows that EC values are in the desirable limit in most of the Lahore region, but moderate increases were observed in southern parts, making it unsuitable for drinking purposes. Spatio-temporal analysis of electrical conductivity shows that the EC concentration varies from $1090 \mu \mathrm{S} / \mathrm{cm}$ to a peak value of $3870 \mu \mathrm{S} / \mathrm{cm}$ in the years 2005 and 2016, respectively.
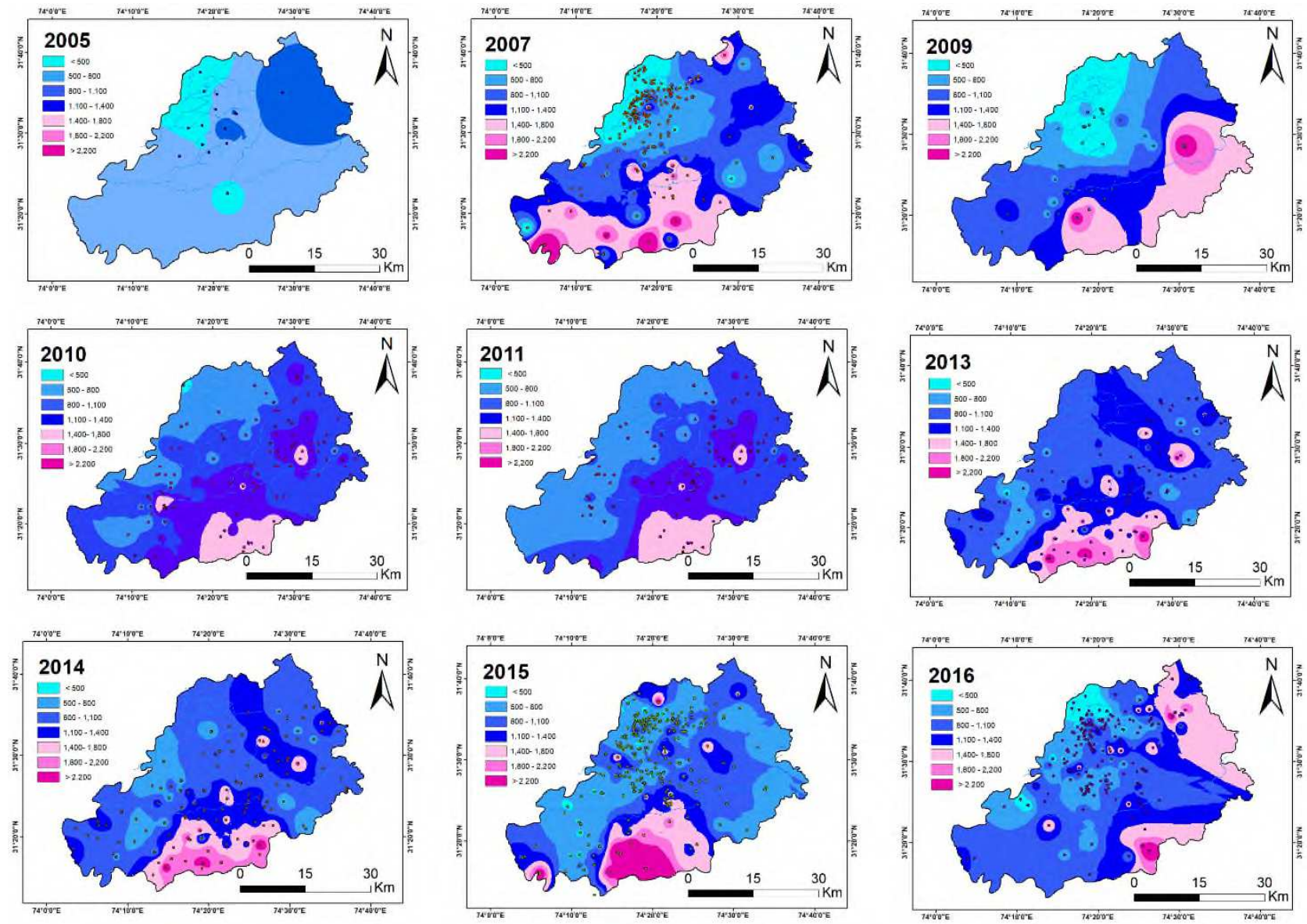

Fig. 5 Spatio-Temporal map of EC in the Lahore region

\section{Total Hardness (TH)}


(TH $<150 \mathrm{mg} / \mathrm{l})$, moderately hard water $(150-300 \mathrm{mg} / \mathrm{l})$, hard water $(300-450 \mathrm{mg} / \mathrm{l})$, and extremely hard water $(\mathrm{TH}$ $>450 \mathrm{mg} / \mathrm{l})$ (Sadat-Noori et al. 2014). The spatial distribution map shows that most of the research area's groundwater lies in the moderate category, which indicates the poor groundwater quality for drinking purposes. It is attributed to the untreated industrial effluents and sewage waste disposal, as shown in Fig. 6. The temporal distribution shows that hardness is average in the starting years. Still, a high concentration plume appeared in the Western part (Iqbal Town) of the Lahore region with a maximum of $1090 \mathrm{mg} / \mathrm{l}$ value.
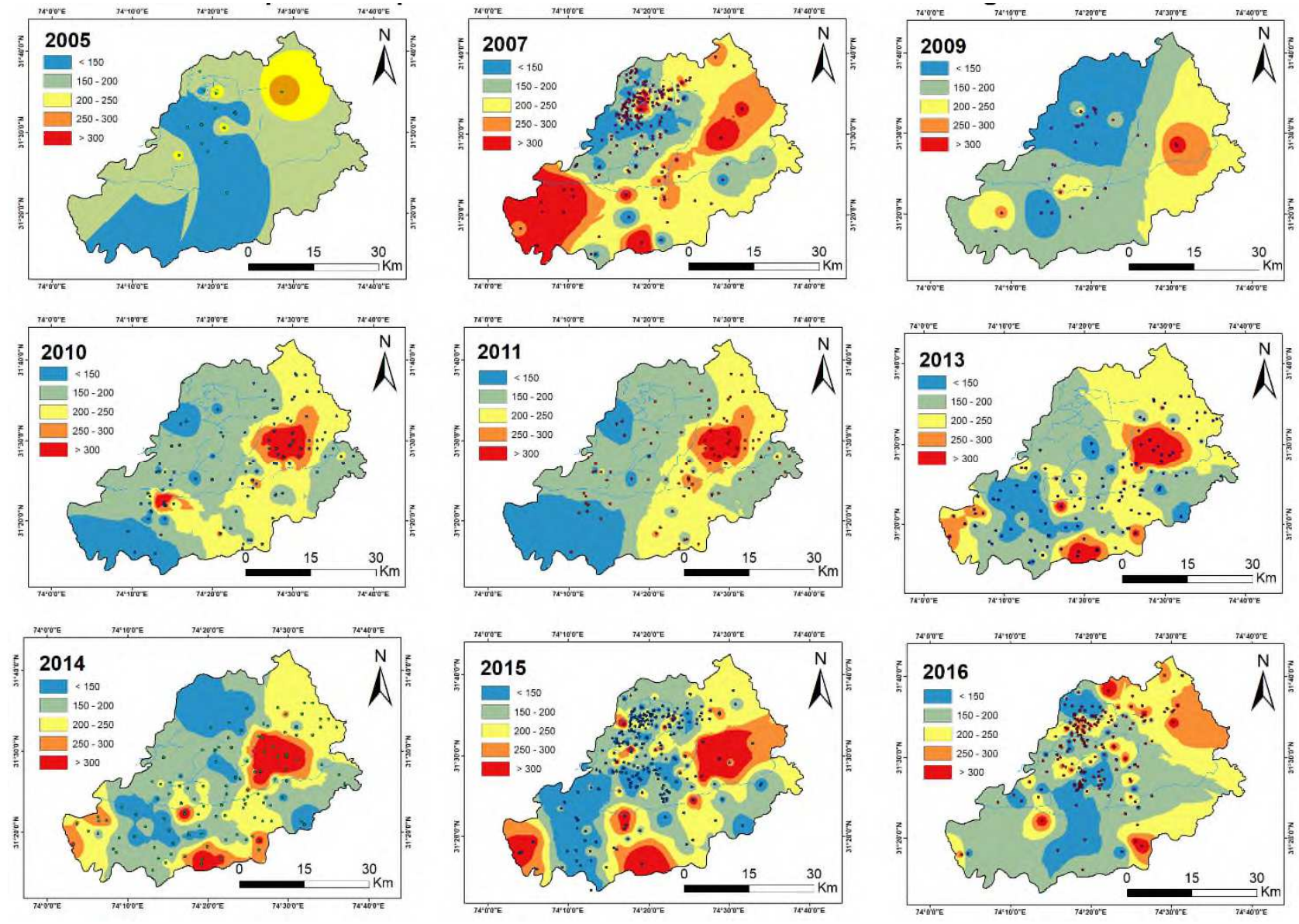

Fig. 6 Spatio-Temporal map of total hardness in the Lahore region

\section{Cations}

A relatively low percentage (up to $6 \%$ for calcium and magnesium) of the samples was found to have calcium and magnesium values exceeding the prescribed values of WHO-recommended limits for drinking water given in Table 3. For both ions, most of the research area is within the WHO standards' permissible limit. In the temporal analysis, mostly the same areas of the Lahore region found prominent with a high concentration of calcium ions. From the year 2005 to 2016, most of the study area showed a random pattern of change in $\mathrm{Ca}^{2+}$ concentration with a peak value of 440mg/l in 2007 in Ravi town. Other regions with more significant values were found in Data Gunj Baksh (Anarkali) and Gulberg town. The spot of Anarkali was also identified for its deteriorating water quality by (Mahmood et al. 2016). Other than the Anarkali region in different years, different areas were highlighted for a high concentration of $\mathrm{Ca}^{2+}$ and $\mathrm{Mg}^{2+}$ leading to hard water problems. 

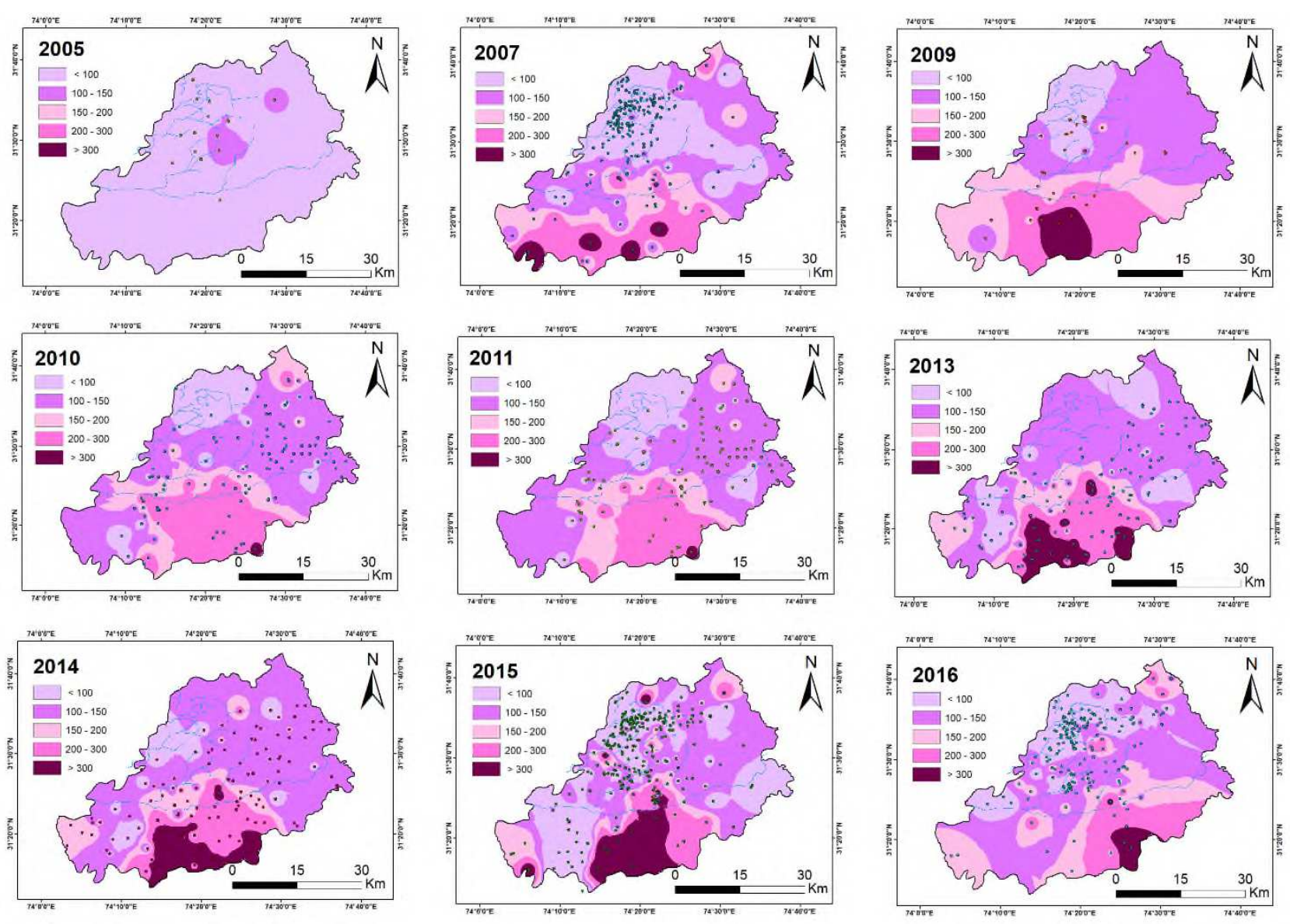

Fig. 7 Spatio-Temporal map of sodium in the Lahore region

Industrial effluents, Improper Sewage Waste, and landfill leachate are the main reasons for groundwater hardness in the research area. (Ibtisam and Ghaffar 2012; Muhammad and Zhonghua 2014). Magnesium exhibiting more or less similar distribution patterns in time series analysis. Results showed the highest values for the years 2007, 2014, 2015, and 2016 were 86mg/l, 77mg/l, 95mg/l, and 75mg/l, respectively. The region of Anarkali was found again prominent in 2007 for $\mathrm{Mg}$ concentration. Overall the concentration of calcium ions was higher than the magnesium ion.

Spatial-temporal map, as shown in Fig. 7, depicts $\mathrm{Na}^{+}$distribution in the study area, which is within the range prescribed by WHO standards in the year 2005 then it starts increasing with a peak value of $460 \mathrm{mg} / \mathrm{l}$ in 2007 in the southern part (Nishtar Town) of Lahore region including western part (Iqbal Town) where most of the land is agriculture. Its concentration increases over time, with the highest value of $770 \mathrm{mg} / \mathrm{l}$ in 2015 in the same southern part of Lahore. As shown in Fig. 8, it was observed that most of the research areas having potassium ions within the WHO limit, except the Eastern and Southern parts of Lahore, which includes Wagha town and Nishtar town. They are prominent in most of the years of analysis. For the temporal window, only in the year 2005 peak concentration of potassium is within limits. In the remaining years, there is a progressive increase in the peak concentration of potassium. The maximum value was observed in 2007 in the Samnabad area of Lahore, $153.6 \mathrm{mg} / \mathrm{l}$. A high concentration plume reappeared in 2015 near the Lahore zoo with a peak value of 145.9mg/l. 

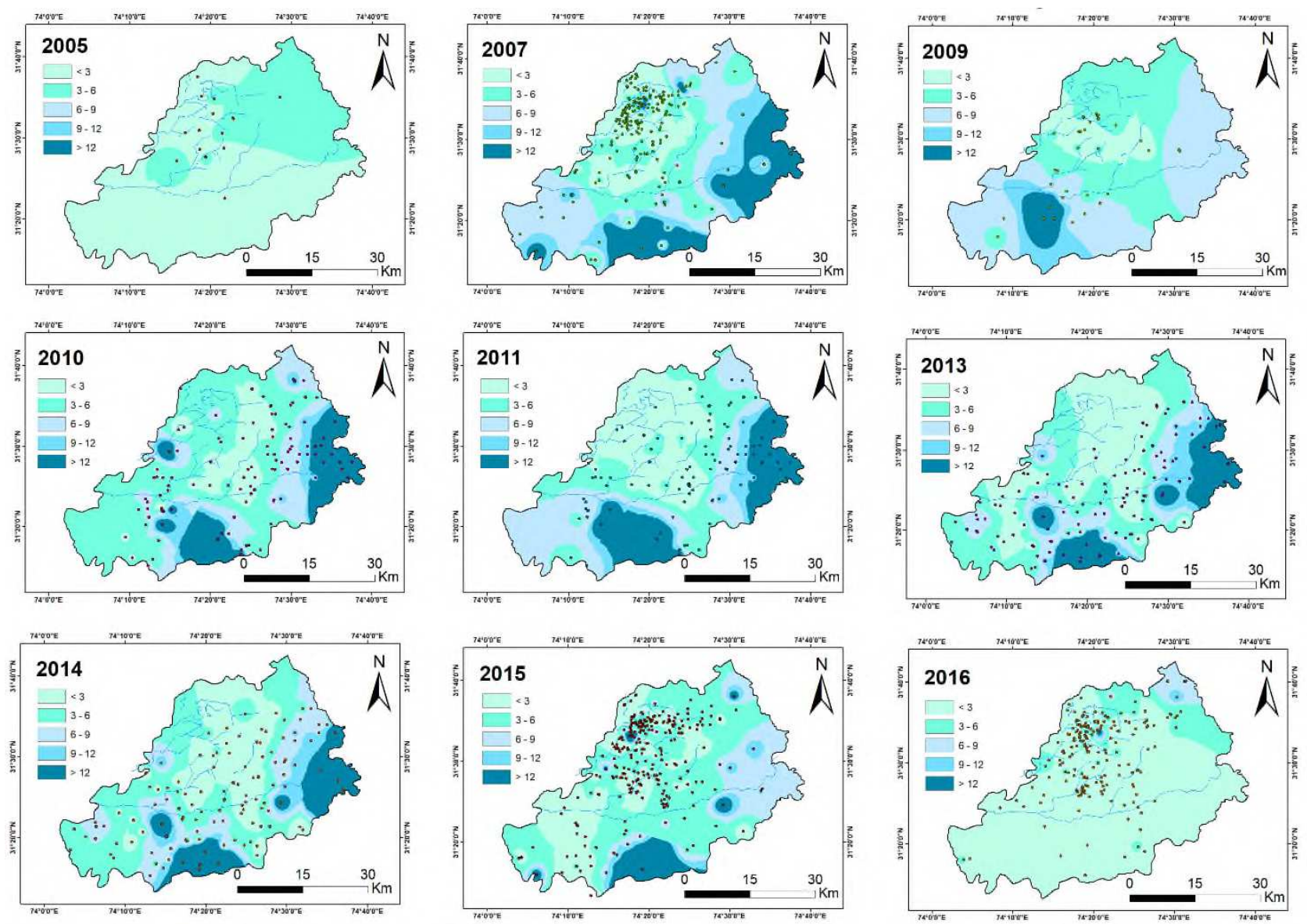

Fig. 8 Spatio-Temporal map of potassium in the Lahore region

\section{Anions}

Municipal or domestic sewage waste, fertilizers, and atmospheric precipitation are the primary sources of $\mathrm{Cl}$ ions in groundwater (Mallick et al. 2018). Low percentages (up to $3 \%$ ) of the samples were found to have $\mathrm{Cl}^{-}$values exceeding the WHO recommended limits for drinking water, as given in Table 3. Its concentration in groundwater has more or less the same distribution pattern in the Lahore region for all the studied years. Chloride exceeded the WHO limit of $250 \mathrm{mg} / \mathrm{l}$ in years 2007, 2009, 2014, 2015 and 2016 with peak values of 276mg/l, 278mg/l, 268mg/l, 379mg/l and $528 \mathrm{mg} / \mathrm{l}$ respectively. These peak values were observed in some areas of Nishter and the Data Ganj Baksh zone of Lahore.

Fig. 9 shows the spatio-temporal distribution of bicarbonate in the area under study. According to spatial distribution maps, $97 \%$ to $100 \%$ of samples, as given in Table 3 , are not in the permissible limit prescribed by the WHO Standards. In the year 2005, the concentration of the $\mathrm{HCO}_{3}$ was quite average. In 2007, a peak value of $950 \mathrm{mg} / \mathrm{l}$ was observed in the southern side (Nishter zone) and the Western part (Allama Iqbal Zone) of the Lahore region. The same peak value of $990 \mathrm{mg} / \mathrm{l}$ reappeared in 2015 and spread again in Lahore's southern part in the Nishter zone. Fertilizers, domestic and sewage wastewater are the primary sources of nitrate in the groundwater. The analysis reveals that $\mathrm{NO}_{3}{ }^{-}$ behavior is quite normal in all the years. Table 3 indicates that no samples were found to have nitrate values exceeding 
the WHO recommended limits. The nitrate concentration in groundwater samples has more or less the same distribution pattern in the Lahore region for all the studied years.
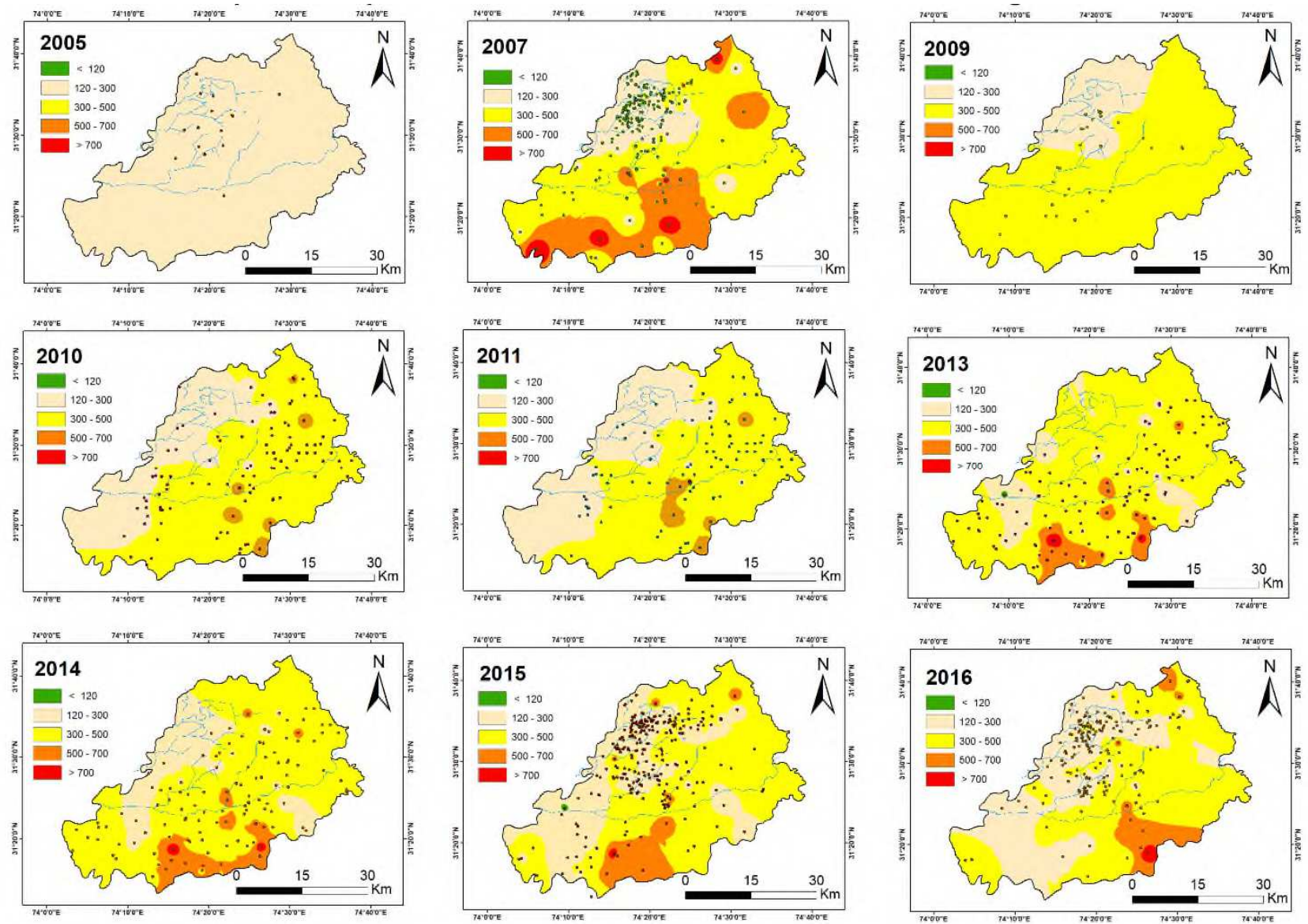

Fig. 9 Spatio-Temporal map of Bicarbonates in the Lahore region

Oxidative weathering of sulfide minerals such as pyrite is the primary source of sulfate in water. However, gypsum and anhydrite can also increase the sulfate ions in drinking water (Tiwari et al. 2018). Sulfates are also derived in minor quantities from air pollutants, fertilizers, and household wastewater (Farooqi et al. 2007). As shown in Table 3 , sulfate concentrations of three to seventeen percent (3-17\%) of the water samples are not within the permissible limit prescribed by WHO standards. Spatio-temporal distribution of sulfate ions, as shown in Fig. 10, exhibits more or less similar distribution patterns. It depicts that the elevated sulfate concentrations were recorded only in few samples every year. Simultaneously, the highest value was observed in 2015, with $800 \mathrm{mg} / \mathrm{l}$ located in Lahore's Southern parts, mostly near industrial areas.

As per the temporal analysis 2005 to 2016, most of the research area showed sulfate concentration higher than WHO prescribed value of $250 \mathrm{mg} / \mathrm{l}$ except for 2005. In 2007 and 2009, a peak value of sulfate ions was observed in the Southern part of Lahore with a value of $470 \mathrm{mg} / \mathrm{l}$ and $603 \mathrm{mg} / \mathrm{l}$ in the Nishter zone and the Western part of 

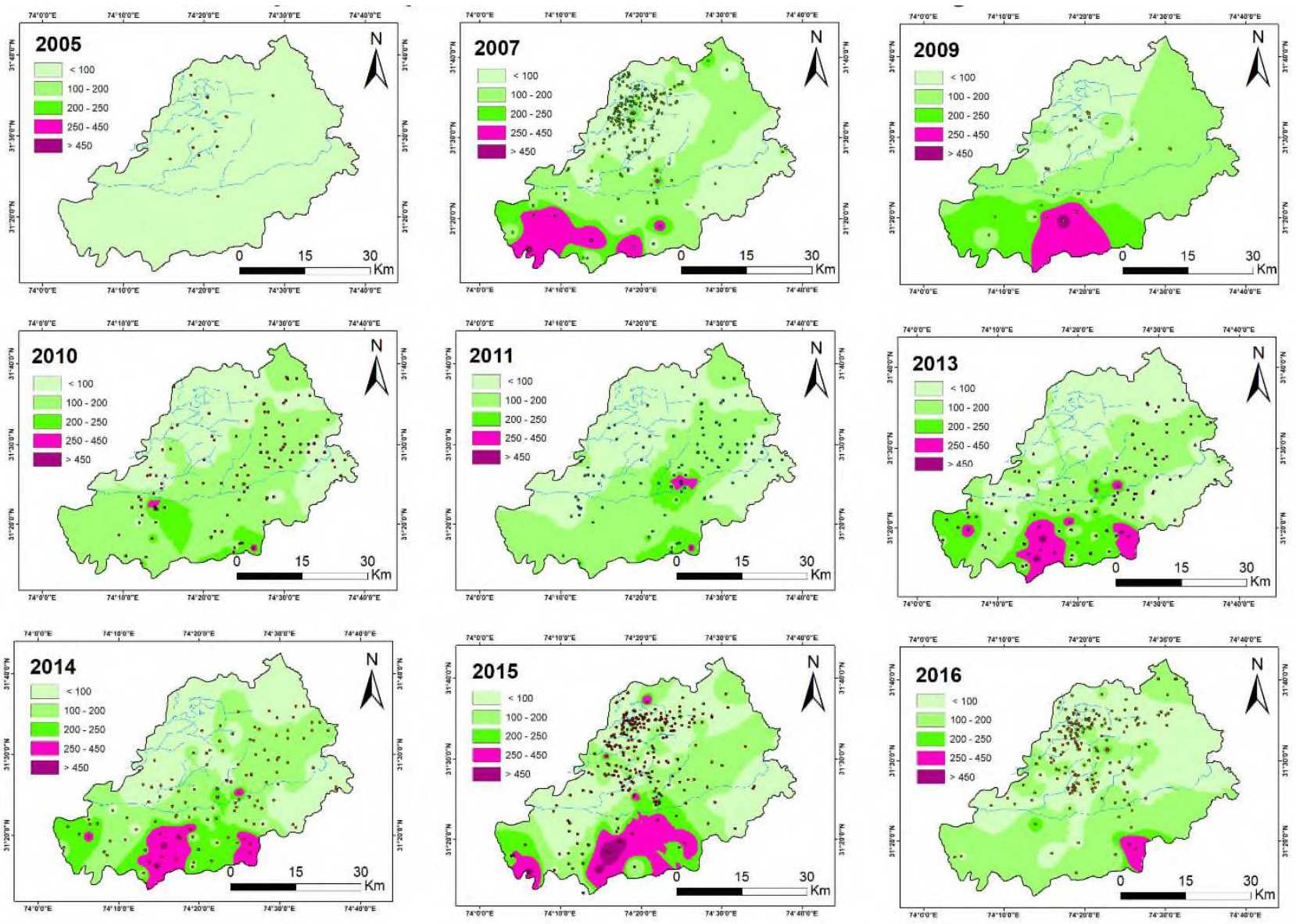

Fig. 10 Spatio-Temporal map of sulfate in the Lahore region

\section{Arsenic}

According to previous studies, along the Ravi River, groundwater quality with respect to arsenic is satisfactory, but it slowly deteriorates in Lahore's Southern and southwestern parts. Water and Sanitation Agency (WASA), Punjab Irrigation Department (PID), Pakistan Council of Research in Water Resources (PCRWR), and the Environmental Protection Agency (EPA) continuously monitoring the groundwater quality and found to be contaminated with Arsenic (Qureshi and Sayed 2014). Relatively high percentages (67\% to 97\%) of the samples in each year were observed to have Arsenic concentrations exceeding WHO standards given in Table 3. Fig. 11 shows the spatio-temporal distribution of arsenic in the research area. From this time series analysis, most groundwater samples have higher arsenic concentrations than $10 \mathrm{ppb}$ (WHO 2004). Spatial disparity maps of each year show the high arsenic concentration in groundwater, and there is no safe zone deducted as prescribed by WHO standards. A peak value of $180 \mathrm{ppb}$ was observed in 2007 from the Northern side of Lahore. This peak value reappeared in the same area in 2010 and 2011 with the highest value of $128.66 \mathrm{ppb}$, and in the years 2013 and 2014, it appeared in the 
southern part of the research area with a peak value of $159.67 \mathrm{ppb}$. Kiln Factories are the major primary source of arsenic contamination, while fertilizers are considered secondary sources (Farooqi et al. 2007; Rasool et al. 2015).
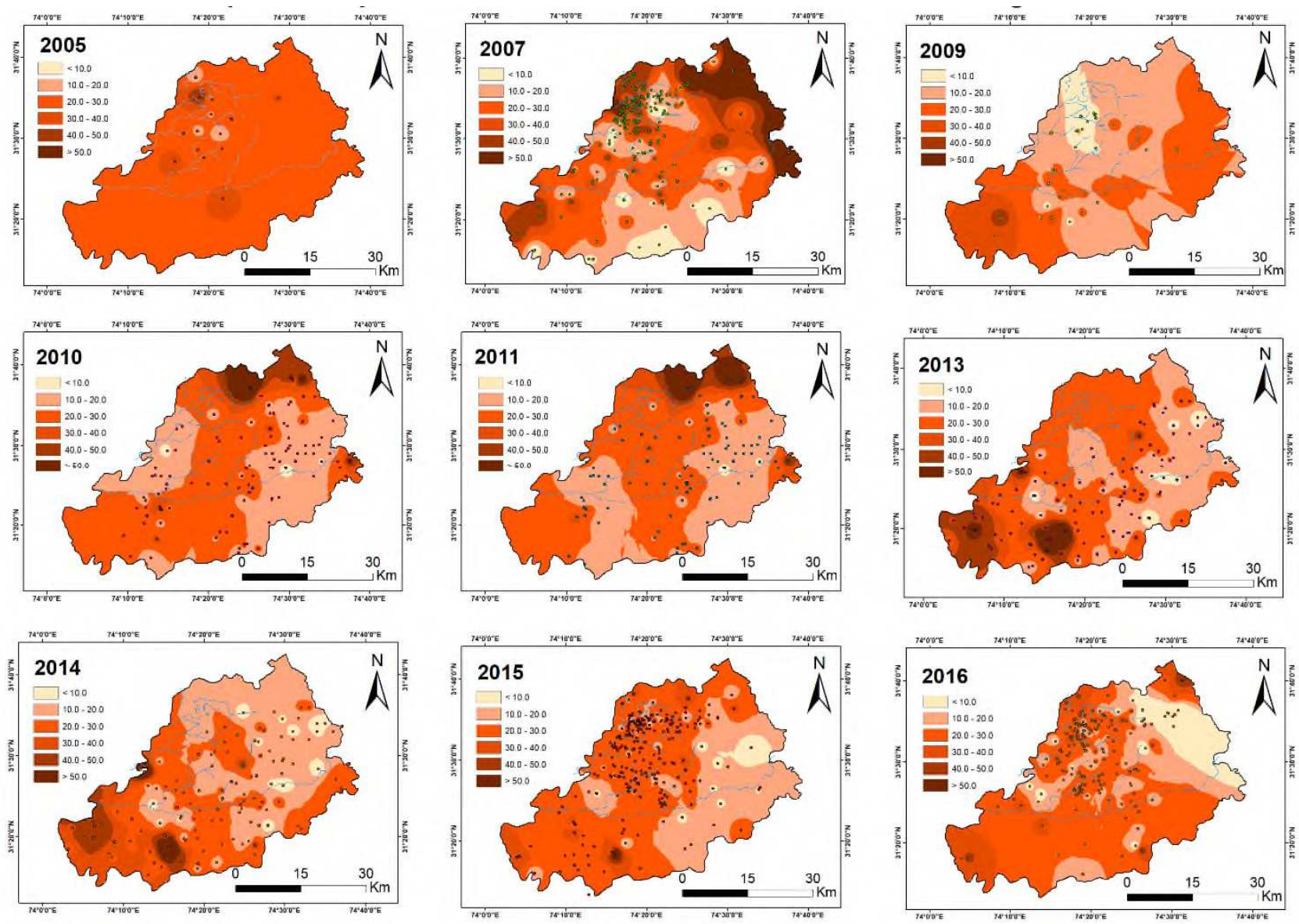

Fig. 11 Spatio-Temporal map of arsenic in the Lahore region

\section{Fluoride}

According to the spatio-temporal distribution, a relatively low percentage (up to $7 \%$ ) of groundwater samples having a concentration of fluoride exceeding $1.5 \mathrm{mg} / \mathrm{l}$ (WHO 2004), as given in Table 3. In the temporal analysis, mostly the same areas of the Lahore region were prominent with a high concentration of fluoride ions. From 2005 to 2016, most of the study area showed a random concentration pattern with a peak value of $7.9 \mathrm{mg} / \mathrm{l}$ in 2007 in the Nishter zone. Other more significant values were found in the same area with a maximum concentration of $3.86 \mathrm{mg} / \mathrm{l}$ for 2010 and 2011 and a peak value of $4.56 \mathrm{mg} / \mathrm{l}$ for years 2013 and 2014. Peak values are also observed in the Allama Iqbal and Wagha zone in 2015 and 2016. The untreated, harmful industrial discharge and domestic sewage wastewater resulted in high fluoride concentration in drinking water (Azizullah et al. 2011; Brahman et al. 2013; Rasool et al. 2015). 
The spatio-temporal distribution of Iron ions concentration reveals that most of the research area lies within

417 WHO limits. In the temporal analysis, mostly the same areas of the Lahore region were prominent with a high iron 418 ion concentration. Most of the study area from the year 2005 to the year 2016 showed more or less the same distribution 419 pattern of Iron concentration with a peak concentration of $2.32 \mathrm{mg} / \mathrm{l}$ in the year 2005 . The peak values of iron concentration in the area were only in the year 2007 is within the WHO standards limit other years exhibit high values in a few areas of Lahore. Low percentages (up to $5 \%$ ) of the samples were found to have iron values exceeding the

422 WHO recommended limits for drinking water, as given in Table 3.

423

Table 3 Permissible Percentage (\%) Calculations

\section{5}

\begin{tabular}{clccc}
\hline No. & Quality Parameter & $\begin{array}{l}\text { No. of } \\
\text { Samples }\end{array}$ & $\begin{array}{l}\text { No. of Samples } \\
\text { Exceeding } \\
\text { Allowable Limits }\end{array}$ & $\begin{array}{l}\text { \%age of Samples } \\
\text { Exceeding Allowable } \\
\text { Limits }\end{array}$ \\
\hline 1 & $\mathrm{pH}$ & 1305 & 94 & $7.2 \%$ \\
2 & $\mathrm{TDS}(\mathrm{mg} / \mathrm{l})$ & 1305 & 777 & $59.5 \%$ \\
3 & $\mathrm{EC}(\mu \mathrm{S} / \mathrm{cm})$ & 1305 & 211 & $16.2 \%$ \\
4 & $\mathrm{TH}(\mathrm{mg} / \mathrm{l})$ & 1305 & 181 & $13.9 \%$ \\
5 & $\mathrm{Ca}(\mathrm{mg} / \mathrm{l})$ & 1305 & 69 & $5.3 \%$ \\
6 & $\mathrm{Mg}(\mathrm{mg} / \mathrm{l})$ & 1305 & 73 & $5.6 \%$ \\
7 & $\mathrm{Na}(\mathrm{mg} / \mathrm{l})$ & 1305 & 229 & $17.5 \%$ \\
8 & $\mathrm{~K}(\mathrm{mg} / \mathrm{l})$ & 1305 & 104 & $8.0 \%$ \\
9 & $\mathrm{Cl}(\mathrm{mg} / \mathrm{l})$ & 1305 & 9 & $0.7 \%$ \\
10 & $\mathrm{As}(\mu \mathrm{g} / \mathrm{l})$ & 1305 & 1112 & $85.2 \%$ \\
11 & $\mathrm{~F}(\mathrm{mg} / \mathrm{l})$ & 1305 & 91 & $7.0 \%$ \\
12 & $\mathrm{Fe}(\mathrm{mg} / \mathrm{l})$ & 1305 & 39 & $3.0 \%$ \\
13 & $\mathrm{HCO}(\mathrm{mg} / \mathrm{l})$ & 1305 & 1290 & $98.9 \%$ \\
14 & $\mathrm{NO}_{3}(\mathrm{mg} / \mathrm{l})$ & 1305 & 0 & $0.0 \%$ \\
15 & $\mathrm{SO}_{4}(\mathrm{mg} / \mathrm{l})$ & 1305 & 105 & $8.0 \%$ \\
\hline
\end{tabular}

\section{Index Method (WQI \& EWQI)}

It is necessary to understand the relationship between the information entropy value $\left(e_{j}\right)$, physicochemical parameters, and entropy weight $\left(\mathrm{w}_{\mathrm{j}}\right)$ before creating the thematic maps of the EWQI and WQI. The entropy theory concept helps to identify the more critical physicochemical parameters affecting groundwater quality with the maximum entropy weight and the minimum information entropy value (Shyu et al. 2011; Jianhua et al. 2011; Gorgij et al. 2017). Table 4 presents the assigned weights (wi) to all 15 quality parameters based on their perceived significance in the drinking water quality, relative weight (Wi), calculated information entropy and entropy weights. Results show that $\mathrm{Fe}(0.210)$, then $\mathrm{NO}_{3}{ }^{-}(0.203), \mathrm{K}(0.164), \mathrm{F}(0.065), \mathrm{SO}_{4}{ }^{2-}(0.052)$, and As $(0.024)$ have the leading role, determining the water quality in the Lahore region. All other parameters with a minimum entropy weight and maximum information entropy have less impact on groundwater quality. 

the research area has been categorized into excellent water (WQI < 50), very good water $(50-70)$, good water $(70-$ 90), fair water (90 - 100), and poor water (WQI > 100). As per these Figs. in 2005, the standard of groundwater quality was reasonable compared to subsequent years, in which WQI of most of the groundwater samples of research areas fall in the good category. GIS-based models of EWQI and WQI reveal similar trends in identifying the low water quality index zones in the research area. Degraded water quality was observed in the next years from 2007 to 2016.

Table 4 Entropy weight, information entropy, and assigned weights to all physicochemical parameters

\begin{tabular}{ccccc}
\hline Parameter & $\begin{array}{c}\text { Information } \\
\text { entropy }\left(\mathbf{e}_{\mathbf{j}}\right)\end{array}$ & $\begin{array}{c}\text { Entropy } \\
\text { weight }\left(\mathbf{w}_{\mathbf{j}}\right)\end{array}$ & $\begin{array}{c}\text { Weight } \\
\left(\mathbf{w}_{\mathbf{i}}\right)\end{array}$ & $\begin{array}{c}\text { Relative } \\
\text { weight }\left(\mathbf{W}_{\mathbf{i}}\right)\end{array}$ \\
\hline $\mathrm{pH}$ & 0.9999 & 0.0001 & 4 & 0.0678 \\
$\mathrm{TDS}(\mathrm{mg} / \mathrm{l})$ & 0.9830 & 0.0269 & 5 & 0.0847 \\
$\mathrm{Ec}(\mu \mathrm{S} / \mathrm{cm})$ & 0.9827 & 0.0274 & 5 & 0.0847 \\
$\mathrm{TH}(\mathrm{mg} / \mathrm{l})$ & 0.9870 & 0.0206 & 2 & 0.0339 \\
$\mathrm{Ca}(\mathrm{mg} / \mathrm{l})$ & 0.9799 & 0.0318 & 3 & 0.0508 \\
$\mathrm{Mg}(\mathrm{mg} / \mathrm{l})$ & 0.9791 & 0.0331 & 3 & 0.0508 \\
$\mathrm{Na}(\mathrm{mg} / \mathrm{l})$ & 0.9657 & 0.0544 & 5 & 0.0847 \\
$\mathrm{~K}(\mathrm{mg} / \mathrm{l})$ & 0.8962 & 0.1644 & 2 & 0.0339 \\
$\mathrm{Cl}(\mathrm{mg} / \mathrm{l})$ & 0.9678 & 0.0511 & 5 & 0.0847 \\
$\mathrm{As}(\mu \mathrm{g} / \mathrm{l})$ & 0.9741 & 0.0411 & 5 & 0.0847 \\
$\mathrm{~F}(\mathrm{mg} / \mathrm{l})$ & 0.9586 & 0.0656 & 5 & 0.0847 \\
$\mathrm{Fe}(\mathrm{mg} / \mathrm{l})$ & 0.8671 & 0.2106 & 4 & 0.0678 \\
$\mathrm{HCO}_{3}(\mathrm{mg} / \mathrm{l})$ & 0.9891 & 0.0173 & 1 & 0.0169 \\
$\mathrm{NO}_{3}(\mathrm{mg} / \mathrm{l})$ & 0.8715 & 0.2036 & 5 & 0.0847 \\
$\mathrm{SO}_{4}(\mathrm{mg} / \mathrm{l})$ & 0.9672 & 0.0520 & 5 & 0.0847 \\
\hline & & $\Sigma \mathrm{W}_{\mathrm{ij}}=1$ & $\Sigma \mathrm{W}_{\mathrm{i}}=59$ & $\Sigma \mathrm{W}_{\mathrm{i}}=1$ \\
\hline
\end{tabular}

444

445

446

447

448

449

450

451

452

453

454

455

456

457

458
A number of spots in the study area were identified in the poor category. One significant plume is in the Northeastern portion of the research area, and others are in the Western and the southern regions near the industrial activities. In the next few years, the southern concentration diluted subsequently from "category poor to category good showing the temporary nature of contaminations. But it reappeared in 2013, and continuous spatial spreading was identified in the Western and Southern regions of Lahore with the poor category. As compared to WQI, the low values of EWQI are observed in most of the research areas, ranked as excellent to good category. Table 5 summarizes the spatio-temporal analysis of WQI and EWQI and enlists the affected Lahore regions concerning their zones.

Table 6 reveals that 100 is the critical limit for WQI and EWQI, indicating that $88 \%$ samples in WQI analysis and $96 \%$ of samples EWQI analysis considered safe for drinking purposes. Muhammad and Zhonghua (2014) and Mahmood et al. (2016) have also studied the few Lahore areas for groundwater quality and identify the same regions with contaminated water. However, with time series analysis from 2005 to 2016 in the present study, the Nishter, Allama Iqbal, Data Gunj Baksh, and Wagha zones have been recognized as a persistent water contamination source (see Table 8). Demographic transition, industrialization, and urbanization exerted extreme pressure on the city area's 
groundwater in excessive pumping generating a deep and large cone of depression in Lahore's urban area. Because of this composite drawdown curve, the seepage water has to travel a long and deep vertical path to become a part of the local aquifer. The possibility of groundwater ability to dissolve different solids, minerals, and ions while traveling through the aquifer material are enhanced, reflecting the low water quality index zones.

463 Table 5 Summary areas with poor WQI and EWQI

\begin{tabular}{|c|c|c|c|}
\hline Sr \# & Directions & Zones of Lahore & Affected Areas of Lahore \\
\hline \multirow[t]{2}{*}{1} & North & Ravi, Shalimar, and Data Ganj Baksh & Mazang, Anarkali \\
\hline & & Town & \\
\hline \multirow[t]{2}{*}{2} & South & Nishter Town & Youhana abad, Pandoki, Bagharain, Gajju \\
\hline & & & Matta, Jia Bagga, Ladeke \\
\hline 3 & East & Wagha Town & Lakhodair, Hudiara, Padhana \\
\hline \multirow[t]{2}{*}{4} & West & Iqbal Town & Raiwind, Manga Mandi, Shahpur, \\
\hline & & & Shamkey bhattian, Sultankay, Pajian \\
\hline 5 & Central Part & Aziz Bhatti and Gulberg Town. & \\
\hline 6 & Northwest & Samanabad Town & Samanabad \\
\hline
\end{tabular}
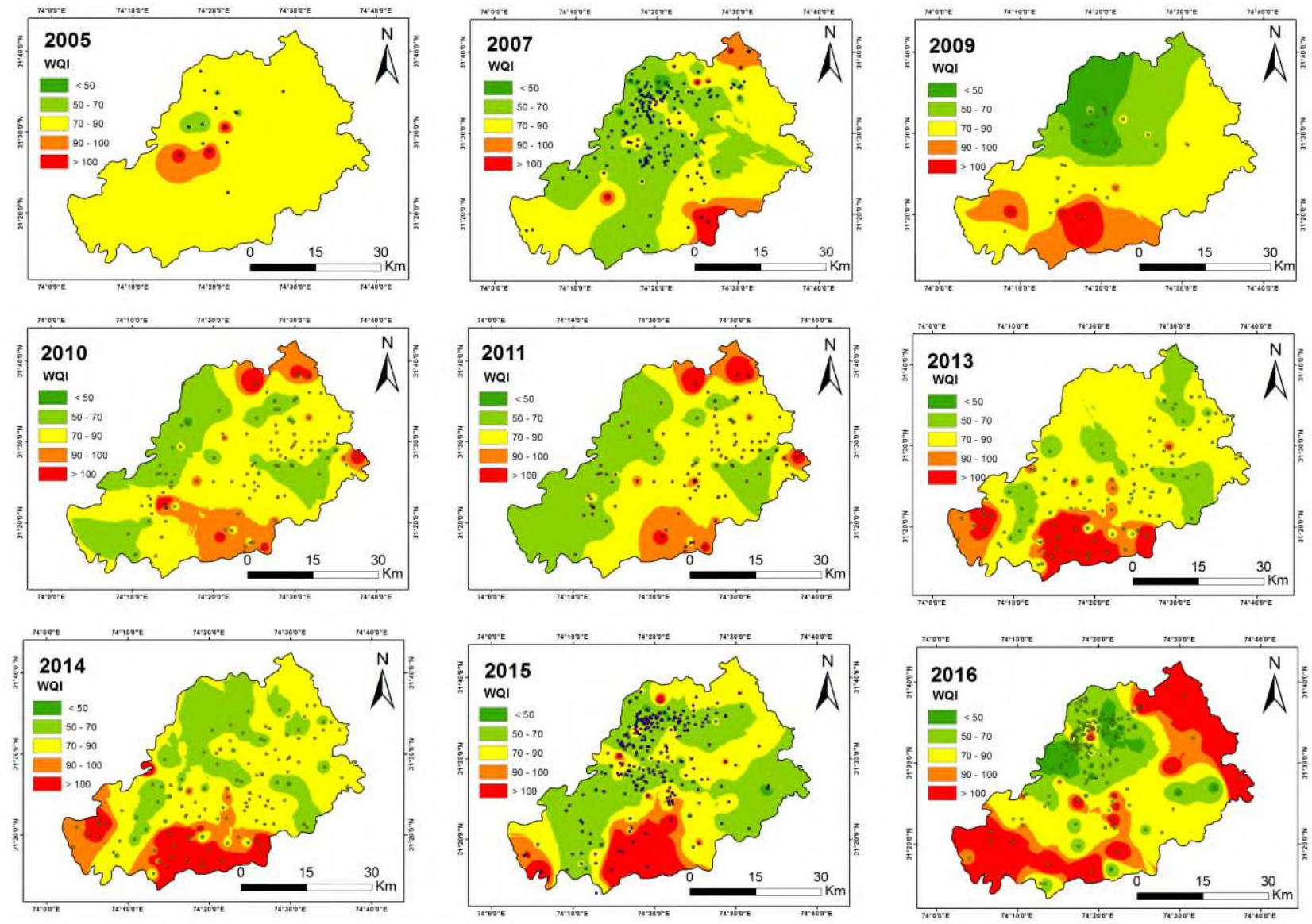

Fig. 12 Spatio-temporal map of WQI in the Lahore Region. 

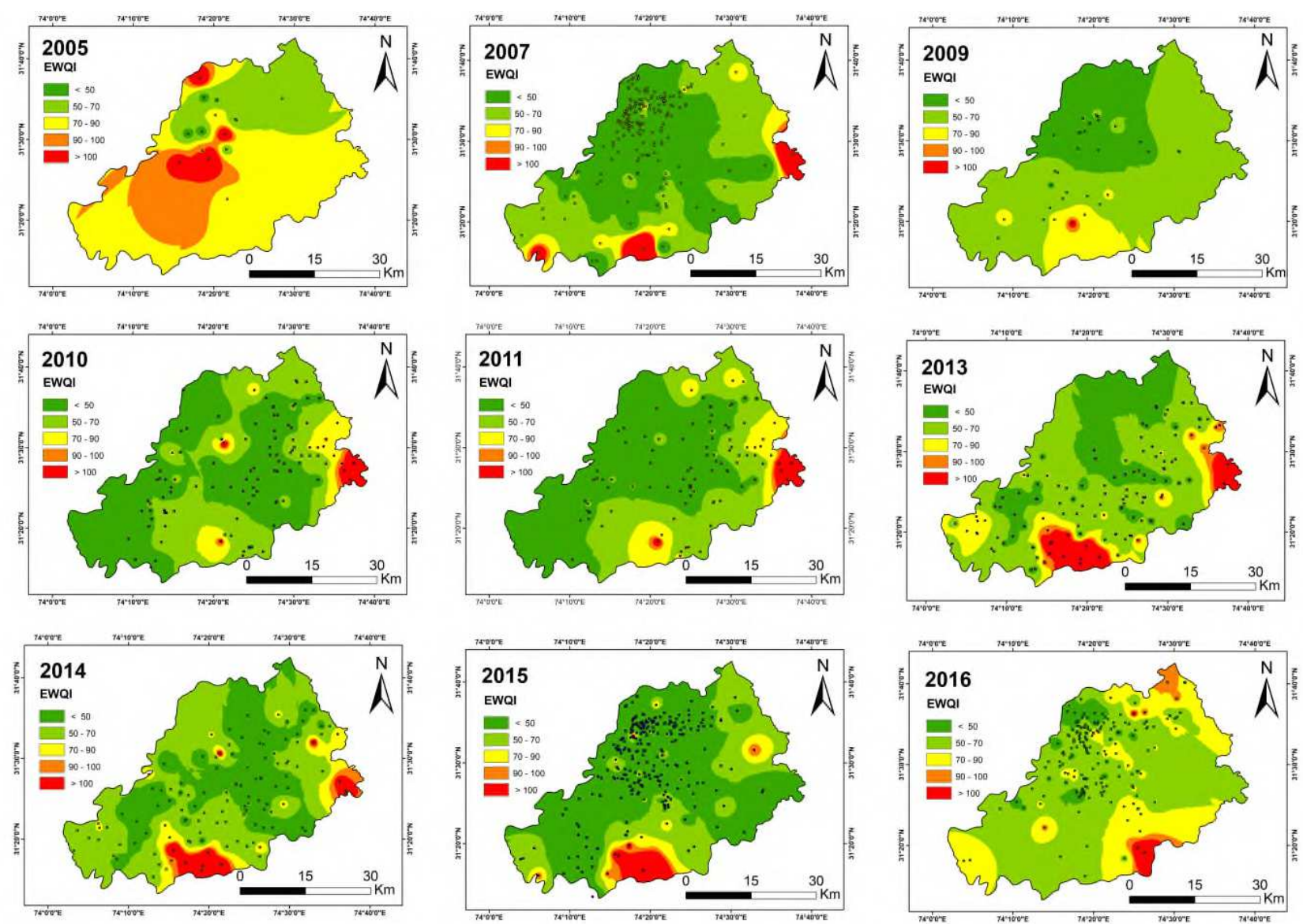

Fig. 13 Spatio-temporal map of EWQI in the Lahore Region.

Table 6 Percentage (\%) calculation of groundwater samples based on WQI and EWQI

\begin{tabular}{ccccc}
\hline Index Method & WQI Range & No. of Samples & \%age & Quality of Water \\
\hline WQI & $<50$ & 139 & $11 \%$ & Excellent \\
& $50-100$ & 1002 & $77 \%$ & Good \\
& $100-200$ & 160 & $12 \%$ & Poor \\
& $200-300$ & 4 & $0 \%$ & Very poor \\
Index Method & $>300$ & 0 & $0 \%$ & Not fit for drinking \\
EWQI & WQI Range & No. of Samples & \% age & Quality of Water \\
& $<50$ & 824 & $63 \%$ & Excellent \\
& $50-100$ & 426 & $33 \%$ & Good \\
& $100-200$ & 51 & $4 \%$ & Poor \\
& $200-300$ & 3 & $0 \%$ & Very poor \\
& $>300$ & 1 & $0 \%$ & Not fit for drinking \\
\hline
\end{tabular}
expansion of Lahore city limits, leading to reduced permeable surfaces (Mahmood et al. 2016). In addition to geogenic activities, other anthropogenic factors are also reported in the research area, which is leachate of municipal solid waste, industrial activities, poor sanitation system. Overall, as per the detailed analysis, it is clear from Fig. 16 that a

477 significant part of the Nisther, Allama Iqbal, and Wagha town falls in the poor water quality index. Other than these 

severe threats to the local population.
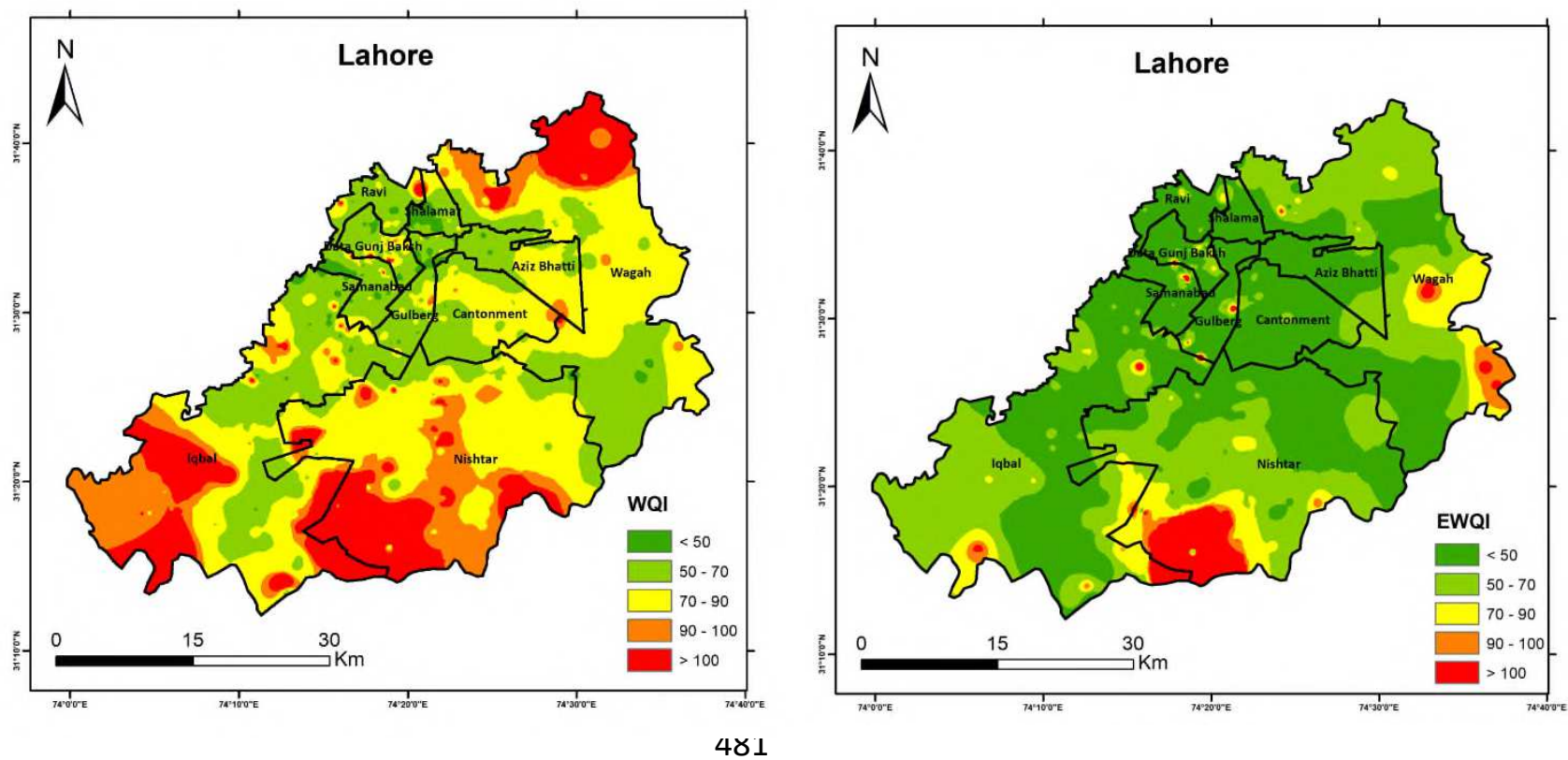

Fig. 14 Summary spatial map of WQI and EWQI in the Lahore Region.

\section{Statistical Analysis}

After performing the spatio-temporal analysis, statistical properties were evaluated to visualize all physicochemical parameters' potential relationship. The statistical measures of all physicochemical parameters like minimum and maximum values, mean, median, skewness, kurtosis, standard deviation, and WHO standard limits are presented in Table 7. The mean value of two quality parameters $\mathrm{HCO}_{3}{ }^{2-}$ and $\mathrm{As}$, are more than the recommended WHO standards as given in Table 7. After a preliminary assessment of the 15 physicochemical parameters under study, the correlation matrix was utilized to identify the correlation coefficients of parameters influencing groundwater's standard quality.

Table 7 Descriptive statistics summary of measured Physicochemical Parameters with WHO standards

\begin{tabular}{lcccccccc}
\hline Parameter & Minimum & Maximum & Mean & Median & Skewness & Kurtosis & $\begin{array}{c}\text { Std- } \\
\text { Dev }\end{array}$ & $\begin{array}{c}\text { WHO } \\
(2004) \\
\text { limit }\end{array}$ \\
\hline $\mathrm{pH}$ & 6.6 & 8.9 & 7.5 & 7.5 & 0.6 & 4.0 & 0.2 & 8.5 \\
$\mathrm{TDS}(\mathrm{mg} / \mathrm{l})$ & 69.0 & 2710 & 565.6 & 495.0 & 1.7 & 7.9 & 294.6 & 1000 \\
$\mathrm{EC}(\mu \mathrm{S} / \mathrm{cm})$ & 108.0 & 2870 & 983.9 & 910.0 & 1.4 & 6.1 & 509.8 & 1400 \\
$\mathrm{TH}(\mathrm{mg} / \mathrm{l})$ & 20.0 & 1070 & 204.0 & 186.8 & 1.6 & 10.1 & 92.1 & 500 \\
$\mathrm{Ca}(\mathrm{mg} / \mathrm{l})$ & 6.0 & 440 & 43.4 & 38.6 & 7.6 & 86.5 & 30.9 & 75 \\
$\mathrm{Mg}(\mathrm{mg} / \mathrm{l})$ & 0.5 & 95 & 25.1 & 22.9 & 1.2 & 5.1 & 14.2 & 50 \\
$\mathrm{Na}(\mathrm{mg} / \mathrm{l})$ & 2.0 & 770 & 135.5 & 115.3 & 2.1 & 10.0 & 101.8 & 200 \\
$\mathrm{~K}(\mathrm{mg} / \mathrm{l})$ & 0.1 & 304 & 6.4 & 3.5 & 11.4 & 198.0 & 13.8 & 12 \\
$\mathrm{Cl}(\mathrm{mg} / \mathrm{l})$ & 5.0 & 528 & 58.4 & 50.0 & 2.8 & 18.9 & 44.1 & 250
\end{tabular}




\begin{tabular}{lcccccccc}
$\mathrm{As}(\mu \mathrm{g} / \mathrm{l})$ & 3.1 & 180 & 24.5 & 23.1 & 3.4 & 26.6 & 16.3 & 10 \\
$\mathrm{~F}(\mathrm{mg} / \mathrm{l})$ & 0.0 & 7.9 & 0.7 & 0.5 & 3.9 & 29.7 & 0.6 & 1.5 \\
$\mathrm{Fe}(\mathrm{mg} / \mathrm{l})$ & 0.0 & 2.32 & 0.1 & 0.0 & 7.7 & 82.4 & 0.1 & 0.3 \\
$\mathrm{HCO}_{3}(\mathrm{mg} / \mathrm{l})$ & 25.0 & 990 & 338.4 & 325.5 & 1.0 & 5.3 & 135.7 & 120 \\
$\mathrm{NO}_{3}(\mathrm{mg} / \mathrm{l})$ & 0.0 & 32 & 0.8 & 0.3 & 11.0 & 184.9 & 1.7 & 45 \\
$\mathrm{SO}_{4}(\mathrm{mg} / \mathrm{l})$ & 8.0 & 800 & 122.1 & 98.4 & 2.1 & 10.3 & 91.1 & 250 \\
\hline
\end{tabular}

As shown in Table 8, numerous physicochemical parameter pairs have a significant positive correlation, indicating identical origin sources, which could be geogenic, or anthropogenic. $\mathrm{EC}$ and $\mathrm{Na}^{+}$exhibit a positive correlation, showing a geogenic source in the research area, from similar origin weathering and disintegration of soil-forming minerals. Simultaneously, insignificant correlations are also observed in other groundwater quality parameters, indicating an independent source of origin.

Table 8 Correlation matrix results of all Physicochemical parameters in the research area

501

\begin{tabular}{|c|c|c|c|c|c|c|c|c|c|c|c|c|c|c|c|}
\hline Parameter & $\mathrm{pH}$ & TDS & $\mathrm{EC}$ & $\mathrm{TH}$ & $\mathrm{Ca}$ & $\mathrm{Mg}^{2+}$ & $\mathrm{Na}^{+}$ & $\mathrm{K}^{+}$ & $\mathrm{Cl}^{-}$ & As & $\mathrm{F}$ & $\mathrm{Fe}$ & $\mathrm{HCO}_{3}{ }^{-}$ & $\mathrm{NO}_{3}{ }^{-}$ & $\mathrm{SO}_{4}{ }^{2}$ \\
\hline $\mathrm{pH}$ & 1 & & & & & & & & & & & & & & \\
\hline TDS & -0.12 & 1 & & & & & & & & & & & & & \\
\hline EC & -0.04 & $\mathbf{0 . 8 9}$ & 1 & & & & & & & & & & & & \\
\hline $\mathrm{TH}$ & -0.02 & 0.44 & 0.49 & 1 & & & & & & & & & & & \\
\hline $\mathrm{Ca}^{2+}$ & 0.03 & 0.03 & 0.04 & 0.26 & 1 & & & & & & & & & & \\
\hline $\mathrm{Mg}^{2+}$ & -0.01 & 0.54 & 0.61 & 0.86 & 0.15 & 1 & & & & & & & & & \\
\hline $\mathrm{Na}^{+}$ & -0.14 & 0.75 & 0.77 & 0.16 & -0.09 & 0.29 & 1 & & & & & & & & \\
\hline $\mathrm{K}^{+}$ & -0.01 & 0.22 & 0.27 & 0.21 & 0.12 & 0.23 & 0.22 & 1 & & & & & & & \\
\hline $\mathrm{Cl}^{-}$ & 0.01 & 0.71 & 0.78 & 0.41 & 0.04 & 0.45 & 0.53 & 0.26 & 1 & & & & & & \\
\hline As & 0.09 & -0.10 & -0.09 & -0.02 & 0.00 & -0.03 & 0.01 & -0.02 & -0.06 & 1 & & & & & \\
\hline $\mathrm{F}$ & -0.10 & 0.27 & 0.24 & 0.07 & -0.03 & 0.15 & 0.26 & 0.10 & 0.19 & -0.16 & 1 & & & & \\
\hline $\mathrm{Fe}$ & 0.05 & -0.01 & -0.05 & 0.00 & -0.05 & 0.00 & -0.04 & 0.00 & -0.04 & -0.02 & -0.08 & 1 & & & \\
\hline $\mathrm{HCO}_{3}{ }^{-}$ & -0.09 & 0.75 & 0.75 & 0.41 & 0.01 & 0.52 & 0.81 & 0.26 & 0.45 & -0.04 & 0.24 & -0.03 & 1 & & \\
\hline $\mathrm{NO}_{3}^{-}$ & 0.10 & 0.16 & 0.11 & 0.08 & 0.06 & 0.12 & 0.06 & 0.10 & 0.08 & -0.11 & 0.07 & 0.06 & 0.17 & 1 & \\
\hline $\mathrm{SO}_{4}{ }^{2-}$ & -0.08 & 0.76 & 0.76 & 0.32 & 0.03 & 0.43 & 0.85 & 0.16 & 0.60 & 0.06 & 0.18 & -0.07 & 0.70 & 0.06 & 1 \\
\hline
\end{tabular}

Bold values shows significant positive correlation between physicochemical parameters

To further understand the impact of physicochemical parameters on groundwater quality, the normalized hydrochemical data was analyzed by employing the Principal Component Analysis (PCA). In this analysis, to recognize the number of principal component factors, an orthogonal Kaiser's varimax rotation and scree plot was utilized. Physicochemical parameters clustered into five groups based on eigenvalues greater than 1. Five factors are representing a cumulative total variance of $69.312 \%$.

The first Principal Component 1 (PC-1), explaining 36.56\% of the total variance, is high loaded with EC,

$510 \mathrm{Na}^{+}, \mathrm{HCO}_{3}{ }^{-}, \mathrm{SO}_{4}{ }^{2-}$, TDS, and $\mathrm{Cl}^{-}$(see Table 9) and moderately loaded with $\mathrm{TH}$ and $\mathrm{Mg}^{+}$. In contrast, in the PC-2, 511 only three parameters $\left(\mathrm{Ca}^{2+}, \mathrm{Mg}^{2+}\right.$, and $\left.\mathrm{TH}\right)$ show moderate loading exhibiting a total variance of $10.5 \%$, representing

512 the same source of origin in the area under study. It is associated with significant ions resulting from geogenic 513 activities, including geochemical processes and weathering of soil-forming minerals (Okiongbo and Douglas 2015;

514 Pazand 2016). This study shows that $\mathrm{Na}^{+}$and $\mathrm{HCO}_{3}{ }^{-}$are the most prominent ions among the analyzed parameters, 515 grouped in the first PC, and strongly correlated. They may be originated from the natural weathering of calcium, 516 magnesium carbonate, bicarbonate, and silicate minerals from the underlying geology. The reverse ion exchange 
517 process may be attributed to the high quantity of $\mathrm{Na}^{+}$ions in the research area's groundwater samples. This study 518 reveals that the high amount of $\mathrm{Ca}^{2+}, \mathrm{Mg}^{2+}$ is also observed in a few of the research area's groundwater samples.

519 Recharge water passes through the alluvial aquifer enriched in calcium and magnesium carbonate minerals, resulting 520 in a high concentration of these ions in groundwater samples (Singh et al. 2008).

521

Table 9 The rotated factors for loading with eigenvalues, percentage of the total variance, and cumulative variance.

\begin{tabular}{cccccc}
\hline & \multicolumn{5}{c}{ Factor } \\
\cline { 2 - 6 } Parameter & $\mathrm{F} 1$ & $\mathrm{~F} 2$ & $\mathrm{~F} 3$ & $\mathrm{~F} 4$ & $\mathrm{~F} 5$ \\
\hline $\mathrm{As}$ & -.070 & .005 & $\mathbf{. 7 9 1}$ & .067 & .178 \\
$\mathrm{HCO}_{3}{ }^{2-}$ & $\mathbf{. 8 4 4}$ & -.132 & .012 & .072 & .007 \\
$\mathrm{Ca}^{2+}$ & .082 & $\mathbf{. 5 7 9}$ & -.020 & -.211 & .275 \\
$\mathrm{Cl}^{-}$ & $\mathbf{. 7 6 2}$ & .013 & .043 & .044 & .034 \\
$\mathrm{EC}$ & $\mathbf{. 9 4 2}$ & -.046 & .035 & .035 & -.013 \\
$\mathrm{~F}$ & .310 & -.214 & -.513 & -.177 & .201 \\
$\mathrm{TH}$ & $\mathbf{. 5 9 0}$ & $\mathbf{. 6 6 9}$ & .044 & -.187 & -.213 \\
$\mathrm{Fe}$ & -.053 & .097 & -.066 & $\mathbf{. 5 6 7}$ & -.665 \\
$\mathrm{Mg}^{2+}$ & $\mathbf{. 6 9 5}$ & $\mathbf{. 5 4 3}$ & .023 & -.116 & -.197 \\
$\mathrm{NO}_{3}{ }^{-}$ & .164 & .176 & -.431 &. $\mathbf{5 5 4}$ & .274 \\
$\mathrm{pH}_{\mathrm{K}}$ & -.100 & .271 & .218 &. $\mathbf{5 9 7}$ & .373 \\
$\mathrm{Na}^{+}$ & .338 & .220 & -.120 & .056 & .326 \\
$\mathrm{SO}_{4}{ }^{2-}$ & $\mathbf{. 8 2 0}$ & -.445 & .100 & .070 & .050 \\
$\mathrm{TDS}^{-}$ & $\mathbf{. 8 4 0}$ & -.244 & .206 & .032 & .031 \\
Eigen value & $\mathbf{. 9 1 3}$ & -.119 & -.030 & .040 & -.055 \\
Total variance $(\%)$ & 5.485 & 1.575 & 1.200 & 1.132 & 1.005 \\
Cumulative variance $(\%)$ & 36.566 & 10.499 & 7.998 & 7.547 & 6.702 \\
\hline
\end{tabular}

The parameters with loadings $>0.50$ are considered significant (remarked in bold)

The third PC (PC-3) is only positively loaded of As with 7.99\% of the total variance. The presence of arsenic reflects different and multiple sources, including natural activities like oxidation reactions and arsenic compound dissolution and human activities such as industrial effluents (Rasool et al. 2015). The fourth PC (PC-4) explains $7.547 \%$ of the total variance moderately loaded with $\mathrm{pH}, \mathrm{NO}_{3}{ }^{-}$, and $\mathrm{Fe}$, indicating an anthropogenic origin source. Their primary source is the sewage wastewater, industrial effluents, and excessive use of fertilizers. The observed iron concentration may also be related to inorganic sulfides' oxidation and weathering of iron-bearing minerals (Okiongbo and Douglas 2015).

The relationship between groundwater chemistry and aquifer lithology can be better understand using the Gibbs plot and Trilinear piper diagram (Gibbs 1970). Gibbs plot is dependent on three standard hydrogeochemical processes: evaporation, precipitation, and rock water interaction mechanism and a generalized classification that 

for 2005 to 2016, as shown in Fig. 15.
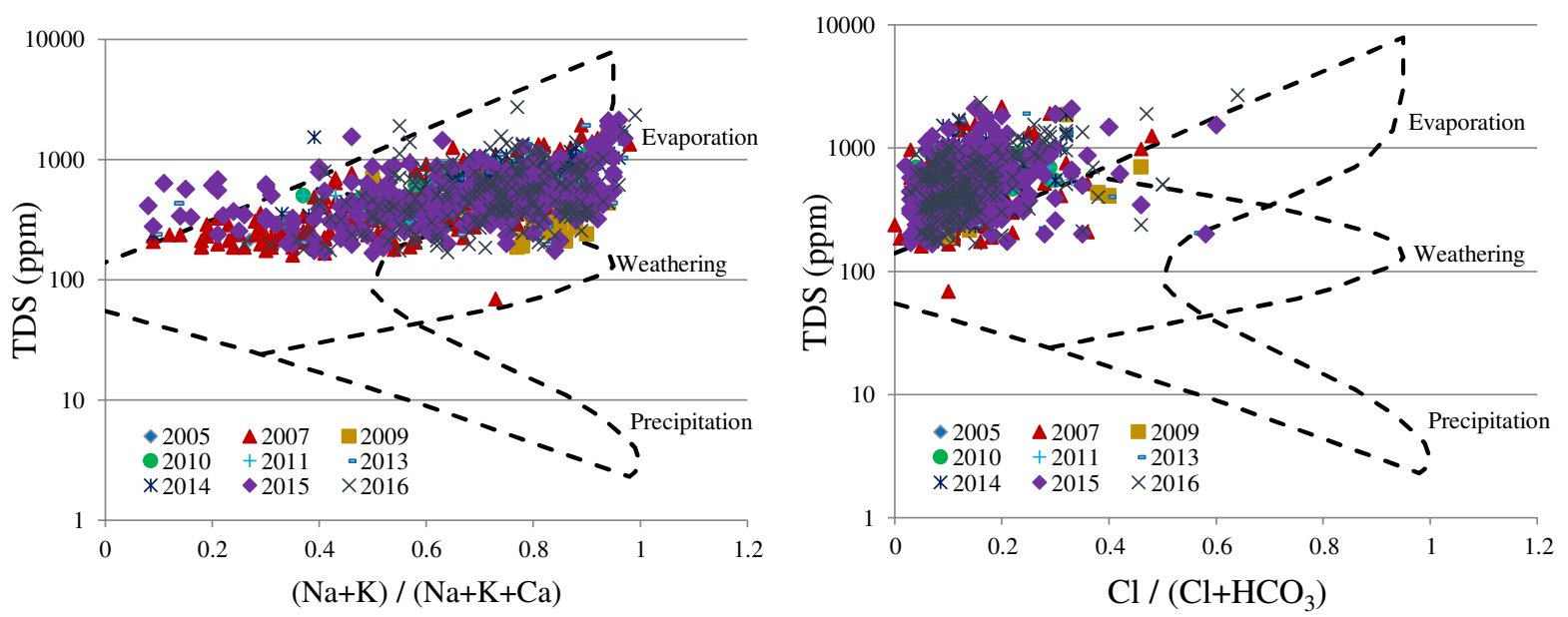

Fig. 15 Gibbs plot for groundwater samples in the research area

Gibbs plot reveals that $91 \%$ of groundwater samples fall under the rock weathering dominance area while only $9 \%$ of samples from all years exist in the evaporation zone. Since the study area is a semi-arid region, evaporation is also a contributing factor to hydrogeochemical processes. The local geology of the research area and ionic chemistry of groundwater samples are measured to understand these processes.

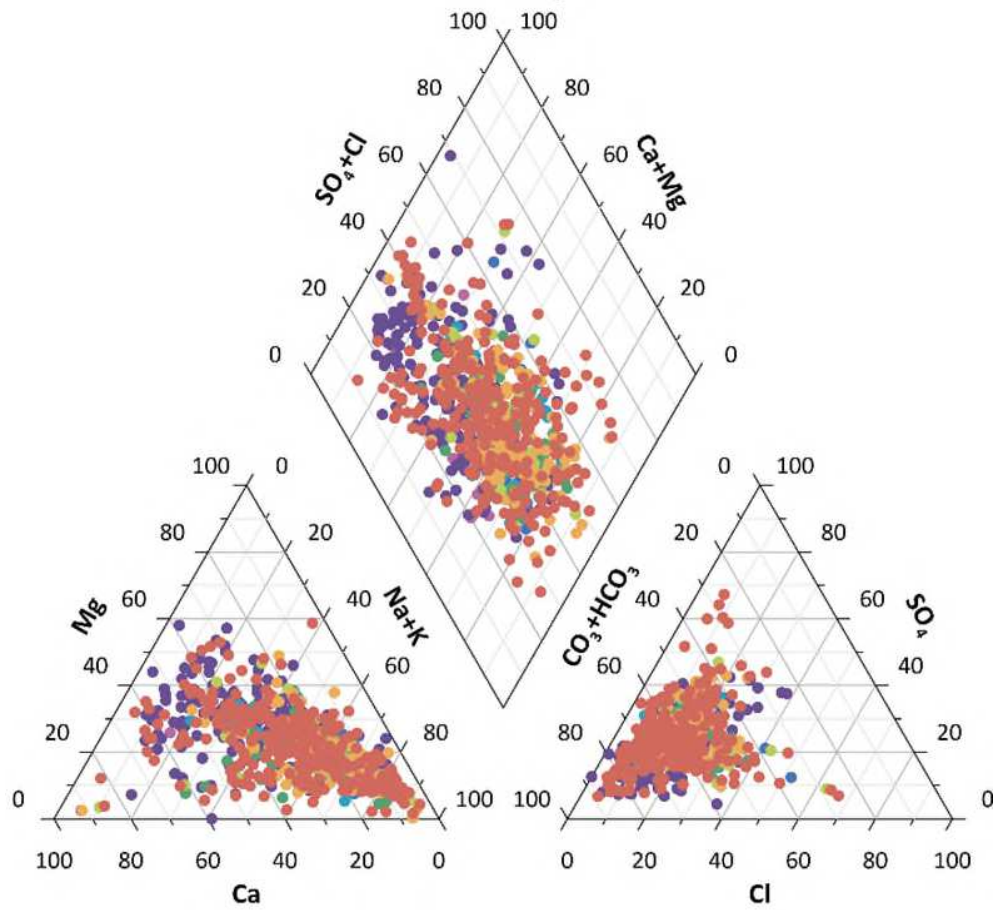

Fig. 16 Piper Trilinear Diagram for groundwater samples in the research area 
Piper diagram is the most commonly used graphical method, plotted to examine the chemical histories and hydrochemical water types for groundwater classification. The Piper Trilinear diagram presented in Fig. 16, from 2005 to 2016, clearly depicts the concentration of cations and anions in the research area. The piper diagram outcome reveals that the combination of ionic parameters of water samples in the Lahore region consists of five major types: $\mathrm{Ca}-\mathrm{Mg}-\mathrm{HCO}_{3}, \mathrm{Na}-\mathrm{Cl}, \mathrm{Ca}-\mathrm{Mg}-\mathrm{Cl}, \mathrm{Na}-\mathrm{HCO}_{3}, \mathrm{Ca}-\mathrm{Na}-\mathrm{HCO}_{3}$. During this study, most groundwater samples fall in the $\mathrm{Ca}-\mathrm{Na}-\mathrm{HCO}_{3}, \mathrm{Ca}-\mathrm{Mg}-\mathrm{HCO}_{3}$ kind of water. Some of them lie in mixed $\mathrm{Ca}-\mathrm{Mg}-\mathrm{Cl}$ type of facies.

\section{CONCLUSIONS}

In this study GIS-based geostatistics tools, including water quality index, entropy water quality index, and multivariate statistical analysis were successfully utilized to analyze the regional level spatio-temporal variation in the physicochemical parameters of groundwater quality. The study involves a large data set of 15 water quality parameters of the groundwater quality parameters (for a period of 2005-2016) of deep aquifers of Lahore region.

The basic statistical analysis shows that concentrations levels of majority of the parameters $(\mathrm{pH}, \mathrm{EC}, \mathrm{TH}$, $\mathrm{Ca}^{2+}, \mathrm{Mg}^{2+}, \mathrm{Na}^{+}, \mathrm{K}^{+}, \mathrm{Cl}^{-}, \mathrm{F}, \mathrm{Fe}, \mathrm{NO}_{3}{ }^{-}$, and $\mathrm{SO}_{4}{ }^{2-}$ ) in groundwater samples are within allowable limits prescribed by the WHO except As, $\mathrm{HCO}_{3}{ }^{-}$and TDS. Overall, the groundwater quality is acceptable in the Northern part of the city near the Ravi River and become progressively worse in the South and Southwestern areas of Lahore. It was also found that more than $85 \%$ of samples from Lahore City are contaminated with arsenic with a peak value of $159.67 \mathrm{ppb}$ that was detected in the southern part of the research area, most likely due to anthropogenic activities like industrial growth and agricultural activities. No zone is declared a safe or arsenic-free zone, and it is quite costly and demanding to restore the quality of groundwater of Lahore city. The number of plumes with poor water quality index has been identified in different parts of the research area. Some of them have expanding trends, including Samanabad, Data Gunj Baksh, Wagha, Nishter, and Allama Iqbal Zone, found as the persistent groundwater contamination source. In rural areas, groundwater quality is affected probably due to the mixing of contaminants generated from the unplanned industrial activities in the surrounding and which is responsible for the degradation of groundwater quality. Municipal solid waste leachate, weak sewerage system, discharge of municipal and industrial effluents in the Ravi River, and different drains passed through the city are other possible groundwater contamination sources.

The spatio-temporal study has enabled identifying the contaminated zones through GIS-based maps of WQI and EWQI. The entropy theory results reveal that $\mathrm{Fe}$, then $\mathrm{NO}_{3}{ }^{-}, \mathrm{K}, \mathrm{F}, \mathrm{SO}_{4}{ }^{2-}$ and As have the leading roles in describing water quality in the Lahore region. The remaining parameters, including $\mathrm{pH}, \mathrm{Na}^{+}, \mathrm{Cl}^{-}, \mathrm{Ca}^{2+}, \mathrm{Mg}^{2+}, \mathrm{EC}, \mathrm{TDS}, \mathrm{TH}$, and $\mathrm{HCO}_{3}{ }^{-}$have a minimum influence on overall groundwater quality with the lowest entropy weight and showed a positive correlation with each other. The principal component analysis confirmed the entropy theory results that these parameters $\left(\mathrm{Fe}, \mathrm{F}, \mathrm{K}, \mathrm{SO}_{4}{ }^{2-}\right.$ and $\left.\mathrm{As}\right)$ required significant attention because they have their independent origination source. The Gibbs diagram and pipper trilinear outcome revealed the concentration of these parameters $\left(\mathrm{Na}^{+}, \mathrm{Cl}^{-}, \mathrm{Ca}^{2+}\right.$, $\mathrm{Mg}^{2+}$, EC, TDS, $\mathrm{TH}$, and $\mathrm{HCO}_{3}^{-}$) are mostly controlled by weathering of soil-forming minerals. These observations testify that the groundwater quality and chemistry of the majority of the study area are influenced mainly by geogenic activities attributed to the weathering and disintegration of the soil-forming minerals and in few areas due to anthropogenic activities related to sewage and industrial wastewater, and agricultural activities. 
The study reveals the effectiveness of the combined utilization of GIS based geostatistical methods and multicriteria statistical analysis techniques at regional level for the evaluation of groundwater contamination and their respective source characterization by using large data sets of groundwater quality parameters.

\section{ACKNOWLEDGEMENT}

The authors wish to thank University of Engineering and Technology, Lahore Pakistan for the financial and laboratory support to conduct this study.

\section{REFERENCES}

Afzal S, Ahmad I, Younas M, et al (2000) Study of water quality of Hudiara drain, India-Pakistan. Environ Int 26:8796. https://doi.org/10.1016/S0160-4120(00)00086-6

Al-hadithi M (2012) Application of water quality index to assess suitability of groundwater quality for drinking purposes in Ratmao -Pathri Rao watershed, Haridwar District, India. Am J Sci Ind Res 3:396-402. https://doi.org/10.5251/ajsir.2012.3.6.395.402

Amiri V, Rezaei M, Sohrabi N (2014) Groundwater quality assessment using entropy weighted water quality index (EWQI) in Lenjanat, Iran. Environ Earth Sci 72:3479-3490. https://doi.org/10.1007/s12665-014-3255-0

APHA (1995) Standard methods for the examination of water and wastewater, 19th edn. American Public Health Association, New York

Azizullah A, Khattak MNK, Richter P, Häder DP (2011) Water pollution in Pakistan and its impact on public health - A review. Environ Int 37:479-497. https://doi.org/10.1016/j.envint.2010.10.007

Bairu A, Bureau WR, Tafesse NT (2020) 10.4314/Ejesm.V5I2.12. Ethiop J Environ Stud Manag. https://doi.org/10.4314/ejesm.v5i2.12

Brahman KD, Kazi TG, Afridi HI, et al (2013) Simultaneously evaluate the toxic levels of fluoride and arsenic species in underground water of Tharparkar and possible contaminant sources: A multivariate study. Ecotoxicol Environ Saf 89:95-107. https://doi.org/10.1016/j.ecoenv.2012.11.023

Charizopoulos N, Zagana E, Psilovikos A (2018) Assessment of natural and anthropogenic impacts in groundwater, utilizing multivariate statistical analysis and inverse distance weighted interpolation modeling: the case of a Scopia basin (Central Greece). Environ Earth Sci 77:1-18. https://doi.org/10.1007/s12665-018-7564-6

Chaurasia AK, Pandey HK, Tiwari SK, et al (2018) Groundwater Quality assessment using Water Quality Index (WQI) in parts of Varanasi District, Uttar Pradesh, India. J Geol Soc India 92:76-82. https://doi.org/10.1007/s12594-018-0955-1

El Alfy M (2010) Integrated Geostatistics and GIS techniques for assessing groundwater contamination in Al Arish area, Sinai, Egypt. Arab J Geosci 5:197-215. https://doi.org/10.1007/s12517-010-0153-y

Farooqi A, Masuda H, Firdous N (2007) Toxic fluoride and arsenic contaminated groundwater in the Lahore and Kasur districts, Punjab, Pakistan and possible contaminant sources. Environ Pollut 145:839-849. https://doi.org/10.1016/j.envpol.2006.05.007

Faunt CC, Ed. (2009) Groundwater Availability of the Central Valley Aquifer, California: U.S. Geological Survey Professional paper 1766 
Fetter, C. W., 2013, Applied Hydrogeology. Pearson New International Edition.

Gibbs RJ (1970) Mechanisms controlling world's water chemistry. Science 170:1088-1090

Gong G, Mattevada S, O’Bryant SE (2014) Comparison of the accuracy of kriging and IDW interpolations in estimating groundwater arsenic concentrations in Texas. Environ Res 130:59-69. https://doi.org/10.1016/j.envres.2013.12.005

Gorgij AD, Kisi O, Moghaddam AA, Taghipour A (2017) Groundwater quality ranking for drinking purposes, using the entropy method and the spatial autocorrelation index. Environ Earth Sci 76:1-9. https://doi.org/10.1007/s12665-017-6589-6

Hosseinimarandi H, Mahdavi M, Ahmadi H, et al (2014) Assessment of Groundwater Quality Monitoring Network Using Cluster Analysis, Shib-Kuh Plain, Shur Watershed, Iran. J Water Resour Prot 06:618-624. https://doi.org/10.4236/jwarp.2014.66060

Hudak PF (2000) Distribution and sources of arsenic in the southern High Plains Aquifer, Texas, USA. J Environ Sci Heal - Part A Toxic/Hazardous Subst Environ Eng 35:899-913. https://doi.org/10.1080/10934520009377010

Ibtisam B, Ghaffar A (2012) Ground water quality assessment near mehmood boti landfill, lahore, pakistan. Asian J Soc Sci Humanit 1:13-24

Islam ARMT, Ahmed N, Bodrud-Doza M, Chu R (2017) Characterizing groundwater quality ranks for drinking purposes in Sylhet district, Bangladesh, using entropy method, spatial autocorrelation index, and geostatistics. Environ Sci Pollut Res 24:26350-26374. https://doi.org/10.1007/s11356-017-0254-1

Jianhua W, Peiyue L, Hui Q (2011) Groundwater quality in jingyuan county, a semi-humid area in northwest China. E-Journal Chem 8:787-793. https://doi.org/10.1155/2011/163695

Kamrani S, Rezaei M, Amiri V, Saberinasr A (2016) Investigating the efficiency of information entropy and fuzzy theories to classification of groundwater samples for drinking purposes: Lenjanat Plain, Central Iran. Environ Earth Sci 75:. https://doi.org/10.1007/s12665-016-6185-1

Ketata M, Gueddari M, Bouhlila R (2012) Use of geographical information system and water quality index to assess groundwater quality in el khairat deep aquifer (enfidha, central east tunisia). Arab J Geosci 5:1379-1390. https://doi.org/10.1007/s12517-011-0292-9

Magesh NS, Chandrasekar N, Vetha Roy D (2011) Spatial analysis of trace element contamination in sediments of Tamiraparani estuary, southeast coast of India. Estuar Coast Shelf Sci 92:618-628. https://doi.org/10.1016/j.ecss.2011.03.001

Mahmood K, Ul-Haq Z, Batool SA, et al (2016) Application of temporal GIS to track areas of significant concern regarding groundwater contamination. Environ Earth Sci 75:1-11. https://doi.org/10.1007/s12665-015-4844-2

Mallick J, Singh CK, AlMesfer MK, et al (2018) Hydro-geochemical assessment of groundwater quality in Aseer Region, Saudi Arabia. Water (Switzerland) 10:1-14. https://doi.org/10.3390/w10121847

Muhammad AM, Zhonghua T (2014) Municipal solid waste and its relation with groundwater contamination in lahore, Pakistan. Res J Appl Sci Eng Technol 7:1551-1560. https://doi.org/10.19026/rjaset.7.431

Okiongbo KS, Douglas RK (2015) Evaluation of major factors influencing the geochemistry of groundwater using graphical and multivariate statistical methods in Yenagoa city, Southern Nigeria. Appl Water Sci 5:27-37. 
https://doi.org/10.1007/s13201-014-0166-x

P. Balakrishnan (2011) Groundwater quality mapping using geographic information system (GIS): A case study of Gulbarga City, Karnataka, India. African J Environ Sci Technol 5:1069-1084. https://doi.org/10.5897/ajest11.134

Pazand K (2016) Geochemistry and multivariate statistical analysis for fluoride occurrence in groundwater in the Kuhbanan basin, Central Iran. Model Earth Syst Environ 2:1-9. https://doi.org/10.1007/s40808-016-0127-5

Pei-Yue L, Hui Q, Jian-Hua W (2011) Application of set pair analysis method based on entropy weight in groundwater quality assessment -A case study in dongsheng city, northwest China. E-Journal Chem 8:851-858. https://doi.org/10.1155/2011/879683

Pei-Yue L, Hui Q, Jian-Hua W (2010) Groundwater quality assessment based on improved water quality index in

Pengyang County, Ningxia
https://doi.org/10.1155/2010/451304

Qureshi A, Sayed AH (2014) Situation analysis of the water resources of Lahore- Establishing a case for water stewardship. World Wildl fund-Pakistan 3-34

Rasool A, Xiao T, Baig ZT, et al (2015) Co-occurrence of arsenic and fluoride in the groundwater of Punjab, Pakistan: source discrimination and health risk assessment. Environ Sci Pollut Res 22:19729-19746. https://doi.org/10.1007/s11356-015-5159-2

Ravikumar P, Somashekar RK, Angami M (2011) Hydrochemistry and evaluation of groundwater suitability for irrigation and drinking purposes in the Markandeya River basin, Belgaum District, Karnataka State, India. Environ Monit Assess 173:459-487. https://doi.org/10.1007/s10661-010-1399-2

Sadat-Noori SM, Ebrahimi K, Liaghat AM (2014) Groundwater quality assessment using the Water Quality Index and GIS in Saveh-Nobaran aquifer, Iran. Environ Earth Sci 71:3827-3843. https://doi.org/10.1007/s12665-013$2770-8$

Saeedi M, Abessi O, Sharifi F, Meraji H (2010) Development of groundwater quality index. Environ Monit Assess 163:327-335. https://doi.org/10.1007/s10661-009-0837-5

Selvam S, Venkatramanan S, Chung SY, Singaraja C (2016) Identification of groundwater contamination sources in Dindugal district of Tamil Nadu, India using GIS and multivariate statistical analyses. Arab J Geosci 9:. https://doi.org/10.1007/s12517-016-2417-7

Shabbir R, Ahmad SS (2015) Use of Geographic Information System and Water Quality Index to Assess Groundwater Quality in Rawalpindi and Islamabad. Arab J Sci Eng 40:2033-2047. https://doi.org/10.1007/s13369-015-16977

Shyu GS, Cheng BY, Chiang CT, et al (2011) Applying factor analysis combined with kriging and information entropy theory for mapping and evaluating the stability of groundwater quality variation in Taiwan. Int J Environ Res Public Health 8:1084-1109. https://doi.org/10.3390/ijerph8041084

Singh AK, Mondal GC, Kumar S, et al (2008) Major ion chemistry, weathering processes and water quality assessment in upper catchment of Damodar River basin, India. Environ Geol 54:745-758. https://doi.org/10.1007/s00254007-0860-1

Srinivasamoorthy K, Chidambaram S, Prasanna M V., et al (2008) Identification of major sources controlling 
groundwater chemistry from a hard rock terrain - A case study from Mettur taluk, Salem district, Tamil Nadu, India. J Earth Syst Sci 117:49-58. https://doi.org/10.1007/s12040-008-0012-3

Strassberg G (2005) A geographic data model for groundwater systems. Philosophy

Subba Rao N (2002) Geochemistry of groundwater in parts of Guntur district, Andhra Pradesh, India. Environ Geol 41:552-562. https://doi.org/10.1007/s002540100431

Thapa R, Gupta S, Guin S, Kaur H (2017) Assessment of groundwater potential zones using multi-influencing factor (MIF) and GIS: a case study from Birbhum district, West Bengal. Appl Water Sci 7:4117-4131. https://doi.org/10.1007/s13201-017-0571-z

Tiwari AK, Singh AK, Mahato MK (2018) Assessment of groundwater quality of Pratapgarh district in India for suitability of drinking purpose using water quality index (WQI) and GIS technique. Sustain Water Resour Manag 4:601-616. https://doi.org/10.1007/s40899-017-0144-1

Tiwari AK, Singh AK, Singh AK, Singh MP (2017) Hydrogeochemical analysis and evaluation of surface water quality of Pratapgarh district, Uttar Pradesh, India. Appl Water Sci 7:1609-1623. https://doi.org/10.1007/s13201-015-0313-z

Vasanthavigar M, Srinivasamoorthy K, Vijayaragavan K, et al (2010) Application of water quality index for groundwater quality assessment: Thirumanimuttar sub-basin, Tamilnadu, India. Environ Monit Assess 171:595609. https://doi.org/10.1007/s10661-009-1302-1

WHO (2004) Guidelines for drinking water quality: training pack. WHO, Geneva, Switzerland

Yan H, Zou Z (2014) Water quality evaluation based on entropy coefficient and blind number theory measure model. J Networks 9(7): 1986-1874. https://doi.org/10.4304/jnw.9.7.1868-1874

Yaseen M, Salik M, Khan A, et al (2009) Studies on heavy metals status and their uptake by vegetables in adjoining areas of Hudiara drain in Lahore Plant Nutrition View project Digitization of ground water quality in Punjab View project Studies on heavy metals status and their uptake by vegetab. Soil Env 28:7-12 (2003) Issues of Water Resources in Pakistan 
Figures

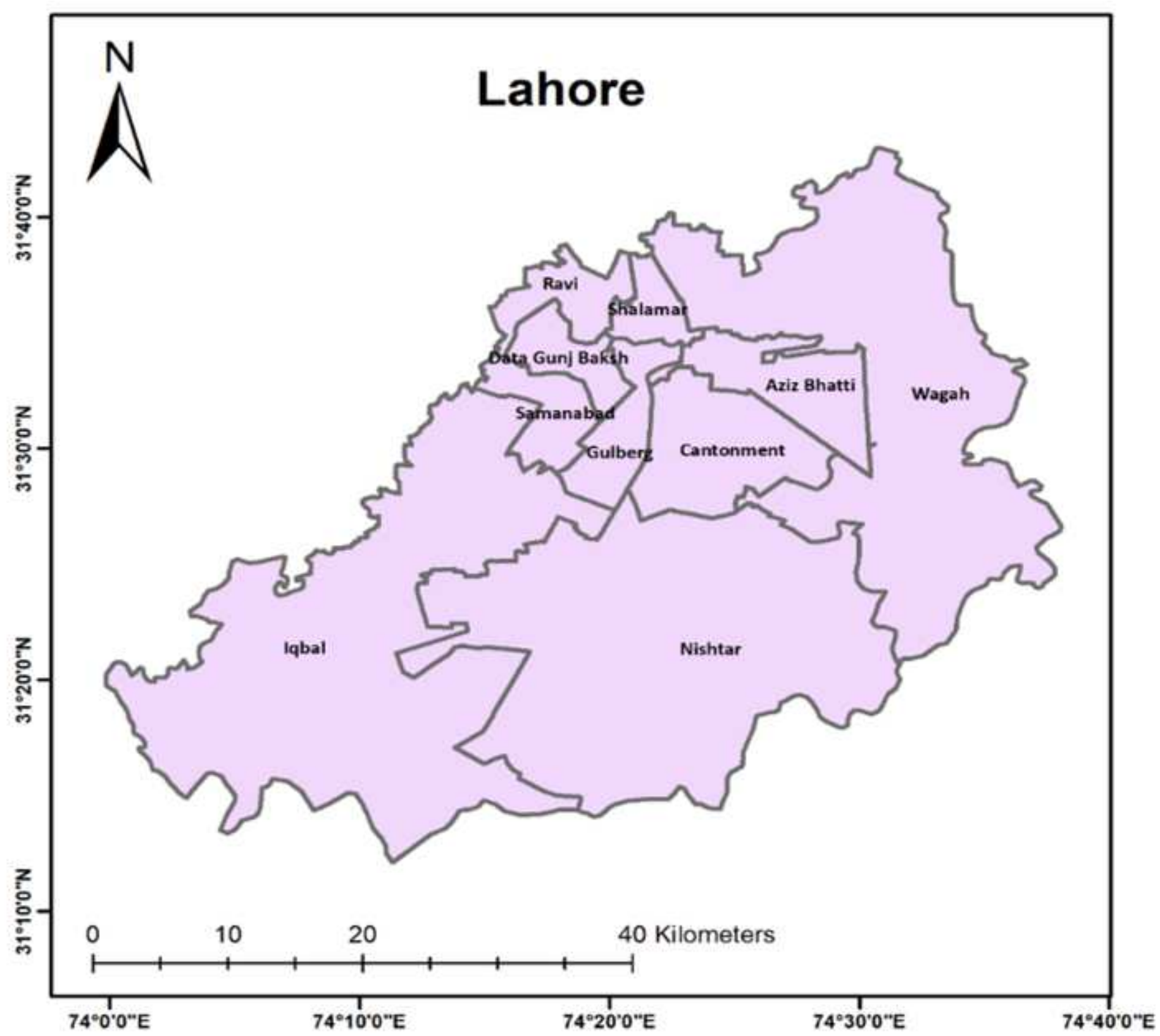

Figure 1

Zonal Classification of the study area Note: The designations employed and the presentation of the material on this map do not imply the expression of any opinion whatsoever on the part of Research Square concerning the legal status of any country, territory, city or area or of its authorities, or concerning the delimitation of its frontiers or boundaries. This map has been provided by the authors. 


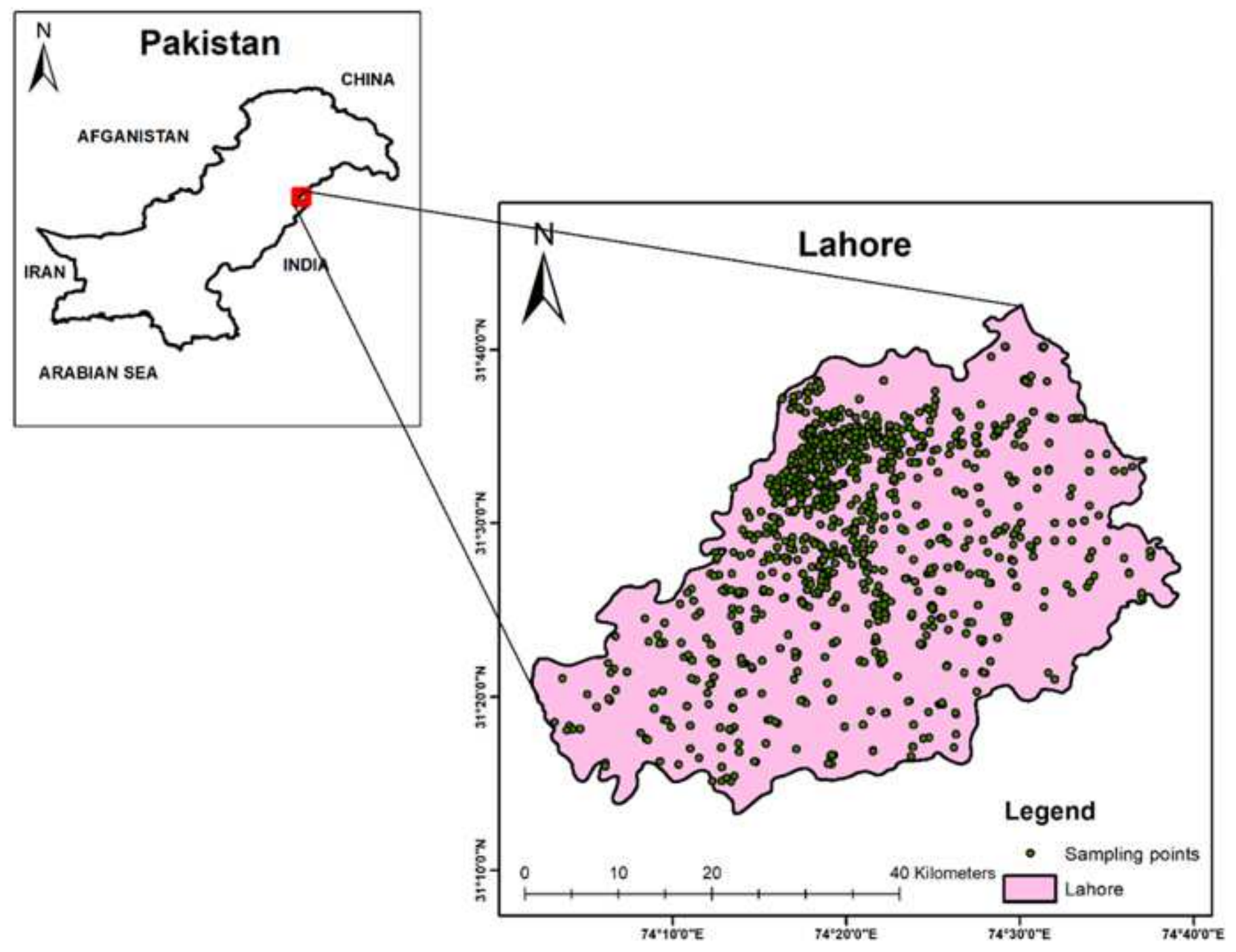

Figure 2

Location of groundwater sampling points in the study area Note: The designations employed and the presentation of the material on this map do not imply the expression of any opinion whatsoever on the part of Research Square concerning the legal status of any country, territory, city or area or of its authorities, or concerning the delimitation of its frontiers or boundaries. This map has been provided by the authors. 

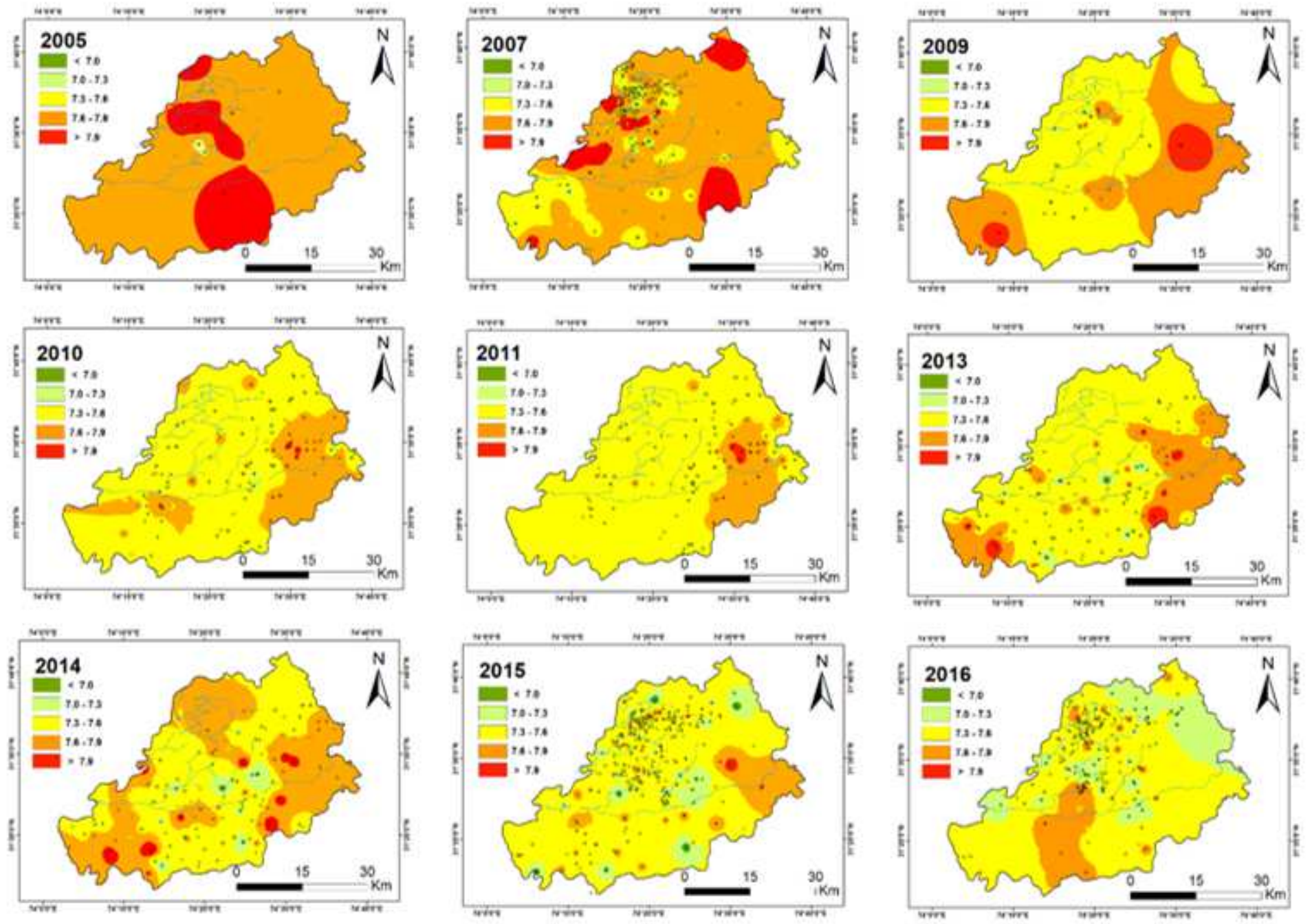

Figure 3

Spatio-Temporal map of $\mathrm{pH}$ in the Lahore region Note: The designations employed and the presentation of the material on this map do not imply the expression of any opinion whatsoever on the part of Research Square concerning the legal status of any country, territory, city or area or of its authorities, or concerning the delimitation of its frontiers or boundaries. This map has been provided by the authors. 

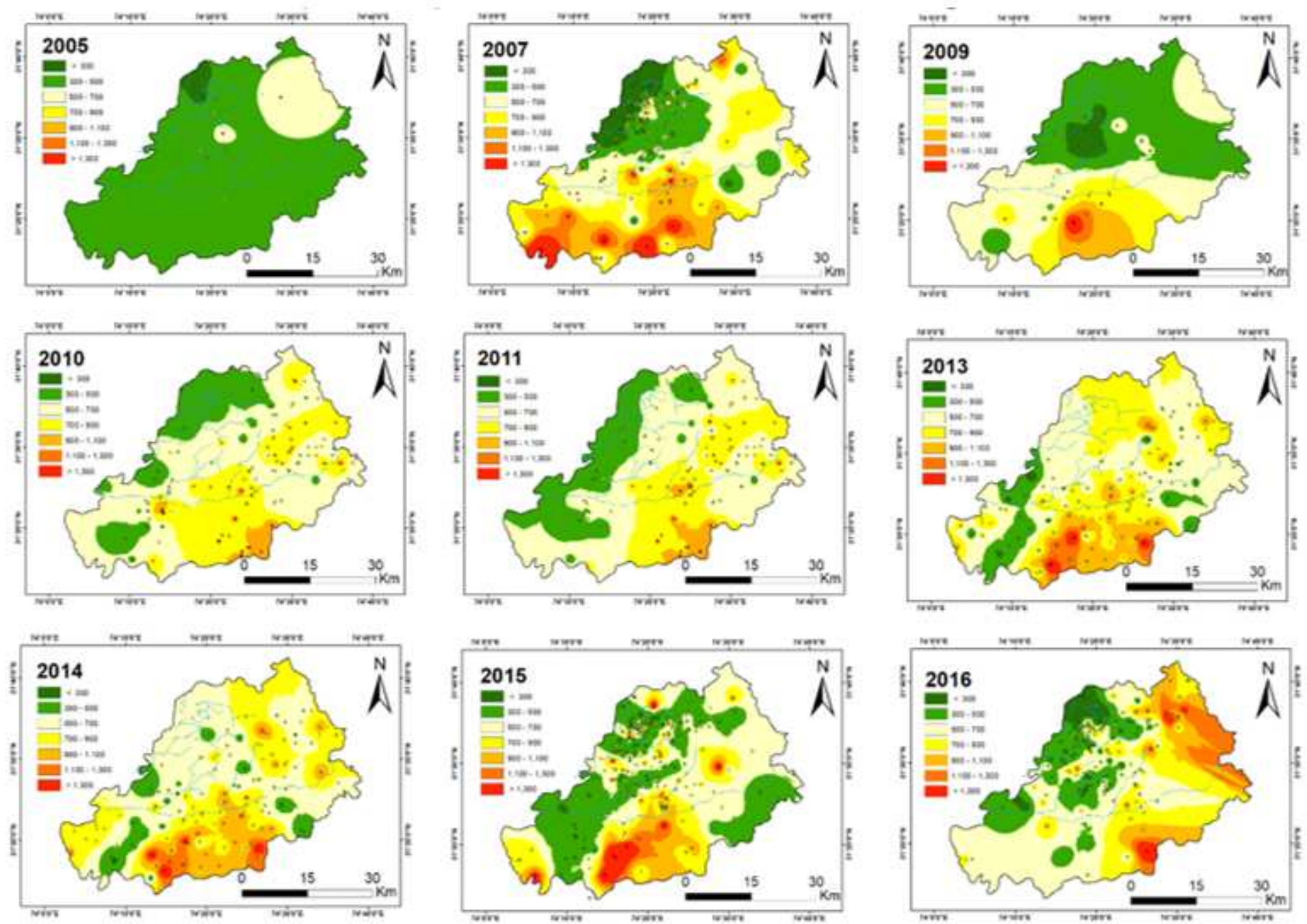

\section{Figure 4}

Spatio-Temporal map of TDS in the Lahore region Note: The designations employed and the presentation of the material on this map do not imply the expression of any opinion whatsoever on the part of Research Square concerning the legal status of any country, territory, city or area or of its authorities, or concerning the delimitation of its frontiers or boundaries. This map has been provided by the authors. 

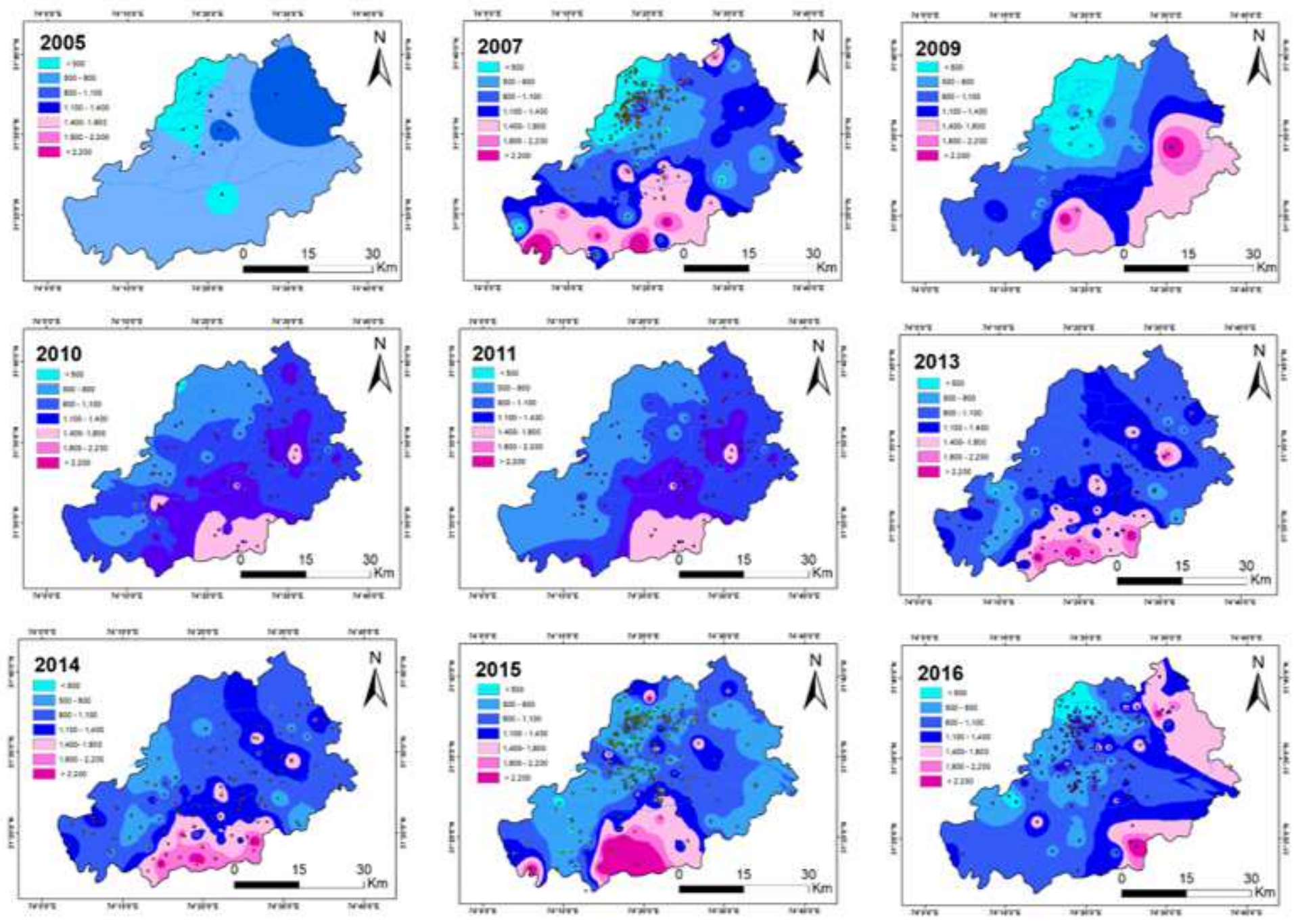

Figure 5

Spatio-Temporal map of EC in the Lahore region Note: The designations employed and the presentation of the material on this map do not imply the expression of any opinion whatsoever on the part of Research Square concerning the legal status of any country, territory, city or area or of its authorities, or concerning the delimitation of its frontiers or boundaries. This map has been provided by the authors. 

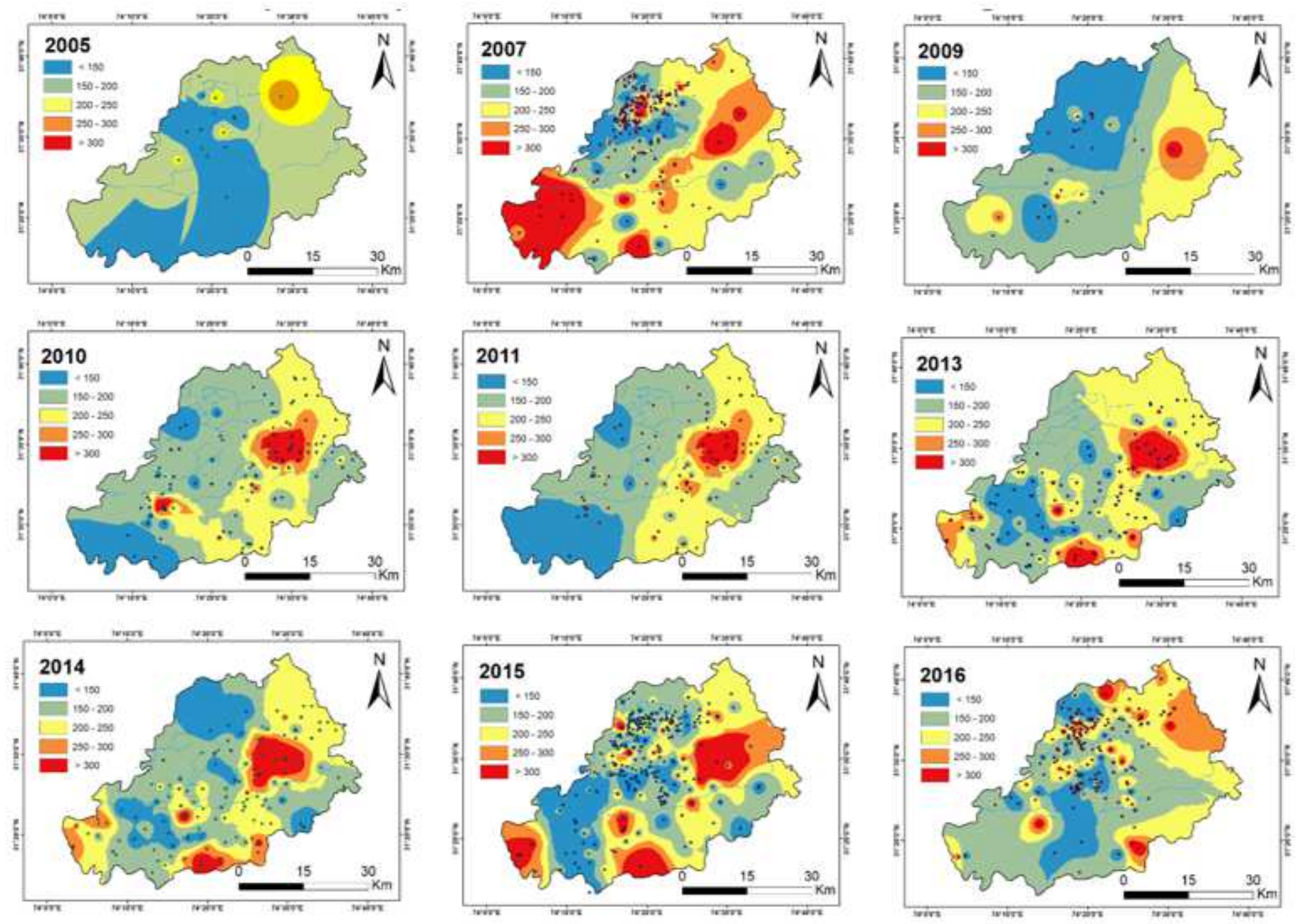

\section{Figure 6}

Spatio-Temporal map of total hardness in the Lahore region Note: The designations employed and the presentation of the material on this map do not imply the expression of any opinion whatsoever on the part of Research Square concerning the legal status of any country, territory, city or area or of its authorities, or concerning the delimitation of its frontiers or boundaries. This map has been provided by the authors. 

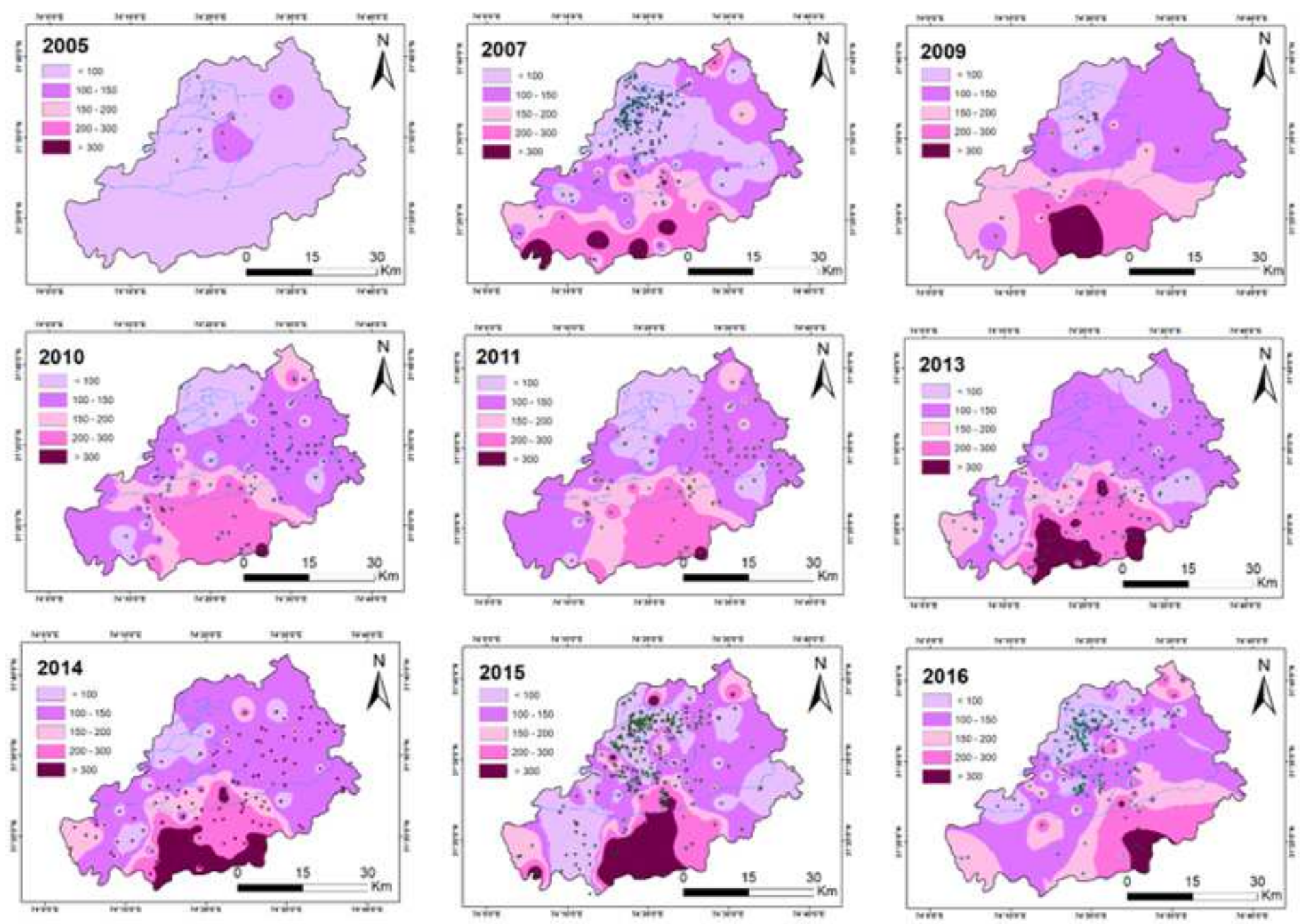

\section{Figure 7}

Spatio-Temporal map of sodium in the Lahore region Note: The designations employed and the presentation of the material on this map do not imply the expression of any opinion whatsoever on the part of Research Square concerning the legal status of any country, territory, city or area or of its authorities, or concerning the delimitation of its frontiers or boundaries. This map has been provided by the authors. 

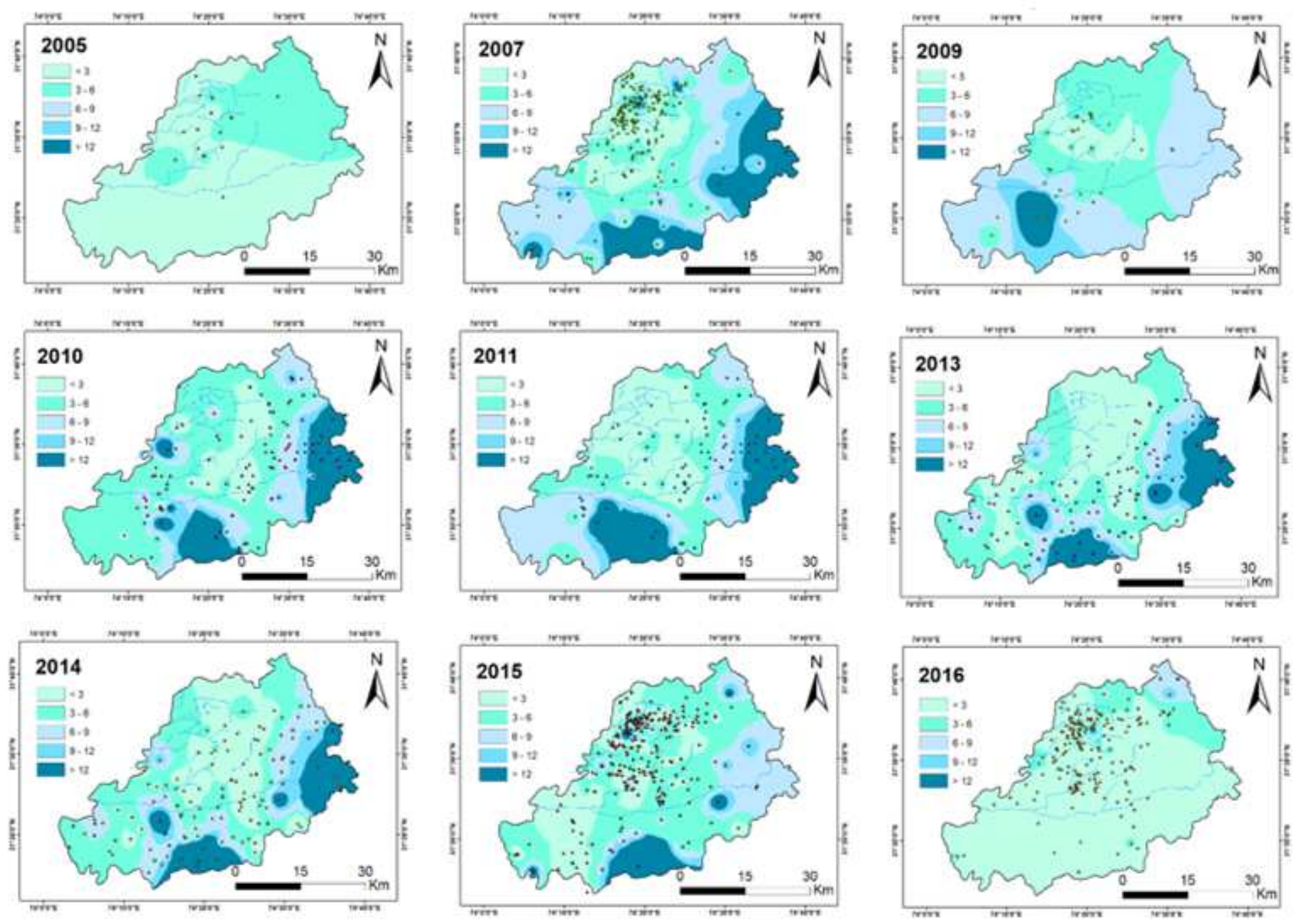

\section{Figure 8}

Spatio-Temporal map of potassium in the Lahore region Note: The designations employed and the presentation of the material on this map do not imply the expression of any opinion whatsoever on the part of Research Square concerning the legal status of any country, territory, city or area or of its authorities, or concerning the delimitation of its frontiers or boundaries. This map has been provided by the authors. 

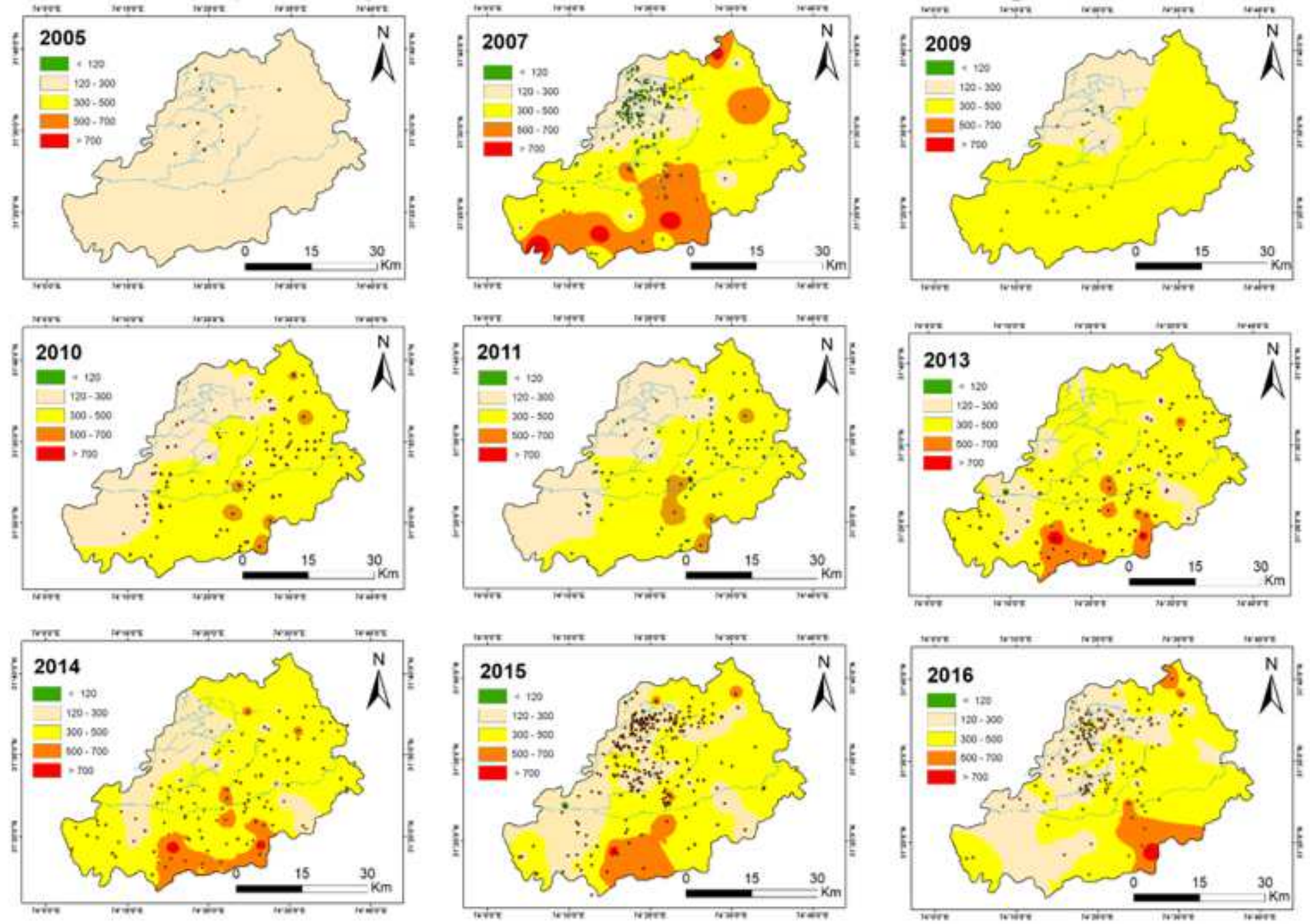

\section{Figure 9}

Spatio-Temporal map of Bicarbonates in the Lahore region Note: The designations employed and the presentation of the material on this map do not imply the expression of any opinion whatsoever on the part of Research Square concerning the legal status of any country, territory, city or area or of its authorities, or concerning the delimitation of its frontiers or boundaries. This map has been provided by the authors. 

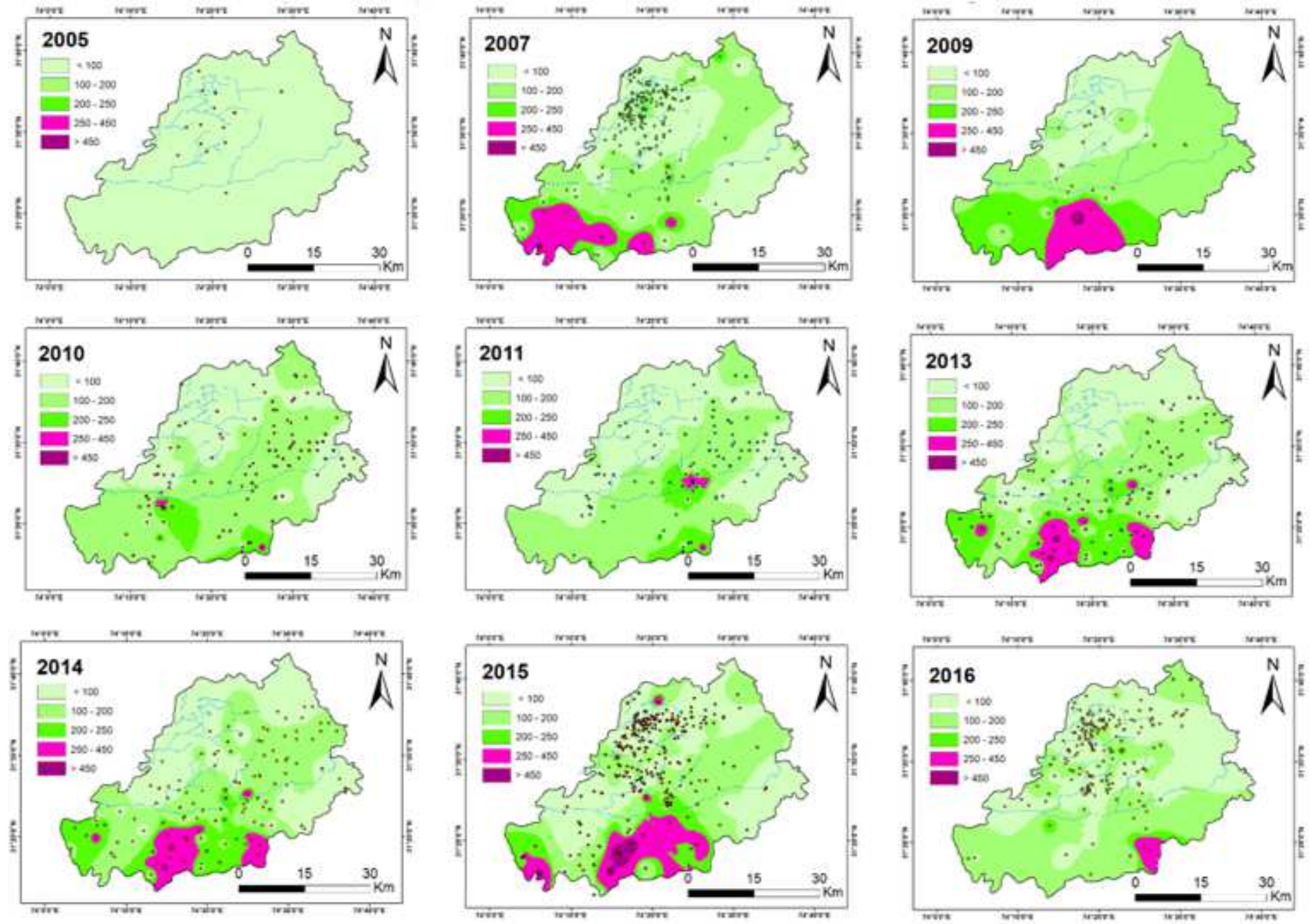

\section{Figure 10}

Spatio-Temporal map of sulfate in the Lahore region Note: The designations employed and the presentation of the material on this map do not imply the expression of any opinion whatsoever on the part of Research Square concerning the legal status of any country, territory, city or area or of its authorities, or concerning the delimitation of its frontiers or boundaries. This map has been provided by the authors. 

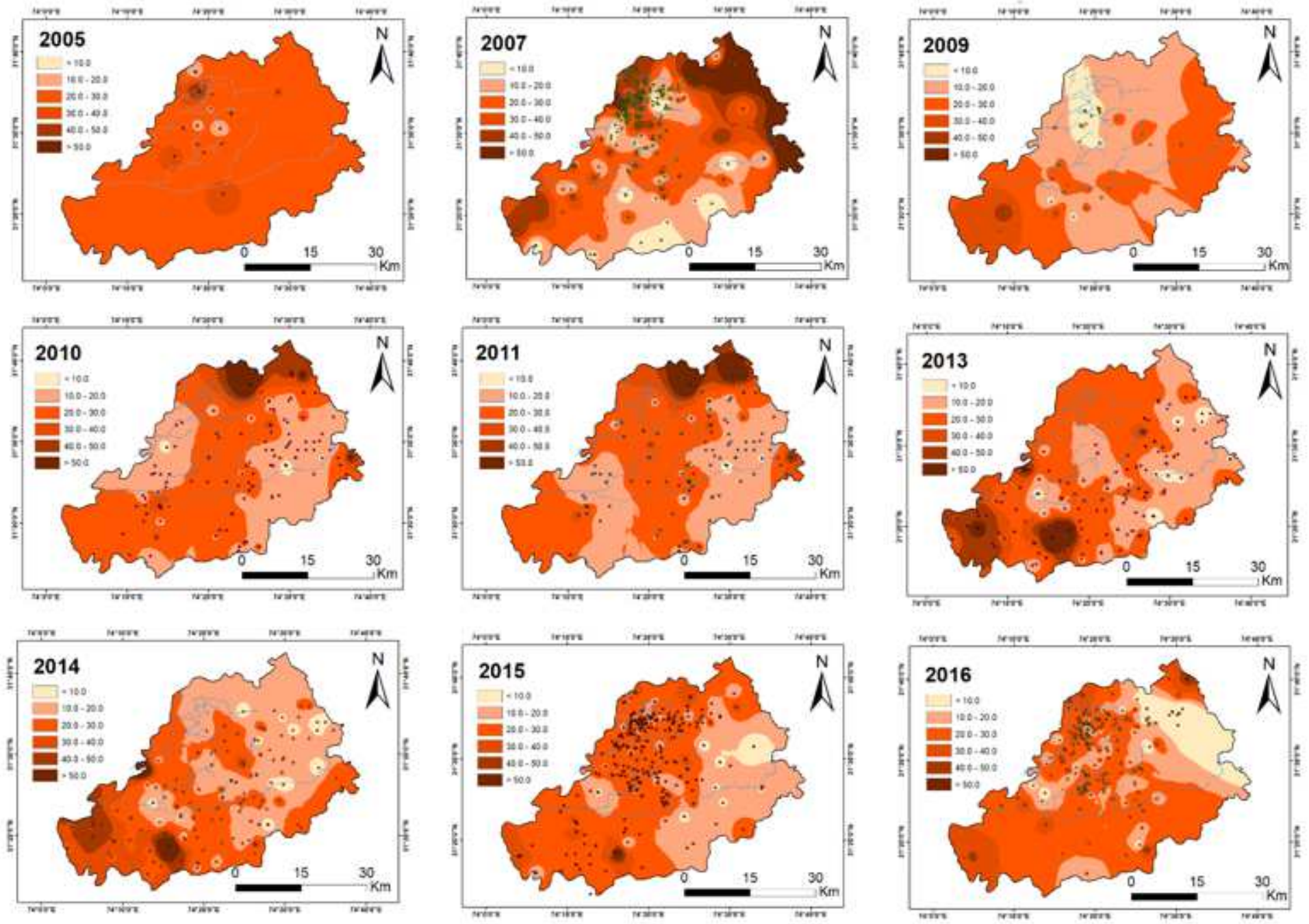

Figure 11

Spatio-Temporal map of arsenic in the Lahore region Note: The designations employed and the presentation of the material on this map do not imply the expression of any opinion whatsoever on the part of Research Square concerning the legal status of any country, territory, city or area or of its authorities, or concerning the delimitation of its frontiers or boundaries. This map has been provided by the authors. 

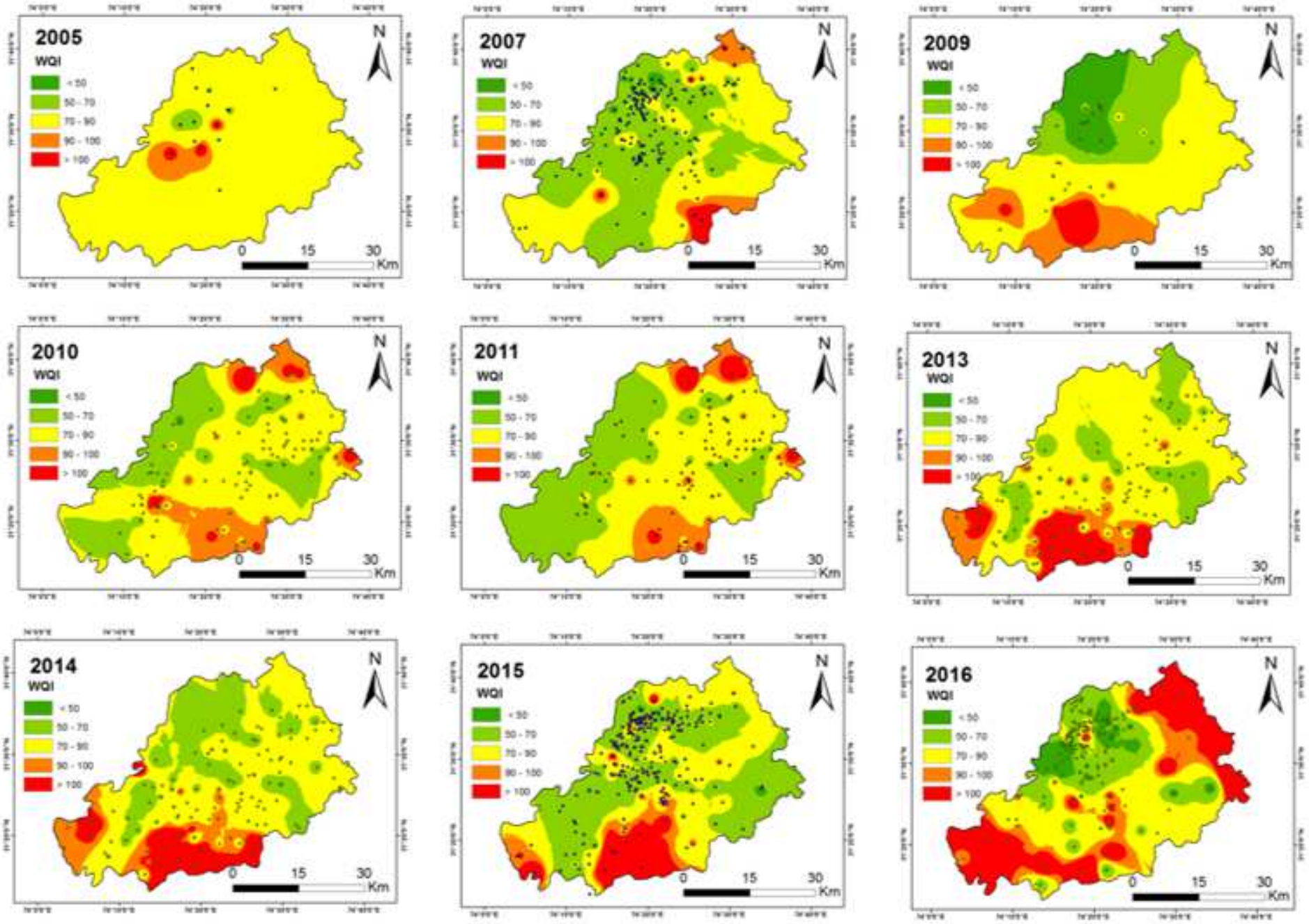

Figure 12

Spatio-temporal map of WQI in the Lahore Region. Note: The designations employed and the presentation of the material on this map do not imply the expression of any opinion whatsoever on the part of Research Square concerning the legal status of any country, territory, city or area or of its authorities, or concerning the delimitation of its frontiers or boundaries. This map has been provided by the authors. 

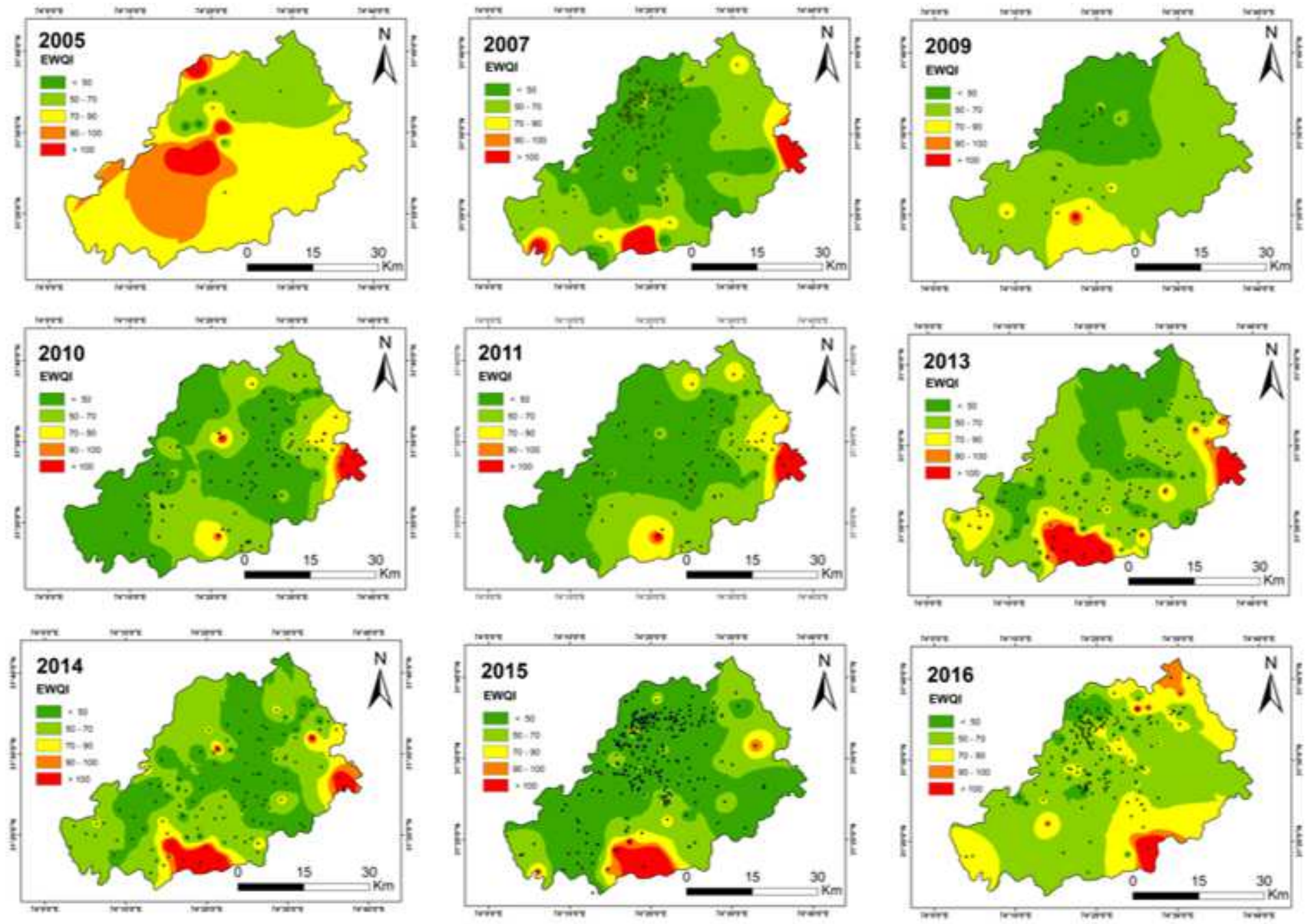

Figure 13

Spatio-temporal map of EWQI in the Lahore Region. Note: The designations employed and the presentation of the material on this map do not imply the expression of any opinion whatsoever on the part of Research Square concerning the legal status of any country, territory, city or area or of its authorities, or concerning the delimitation of its frontiers or boundaries. This map has been provided by the authors. 

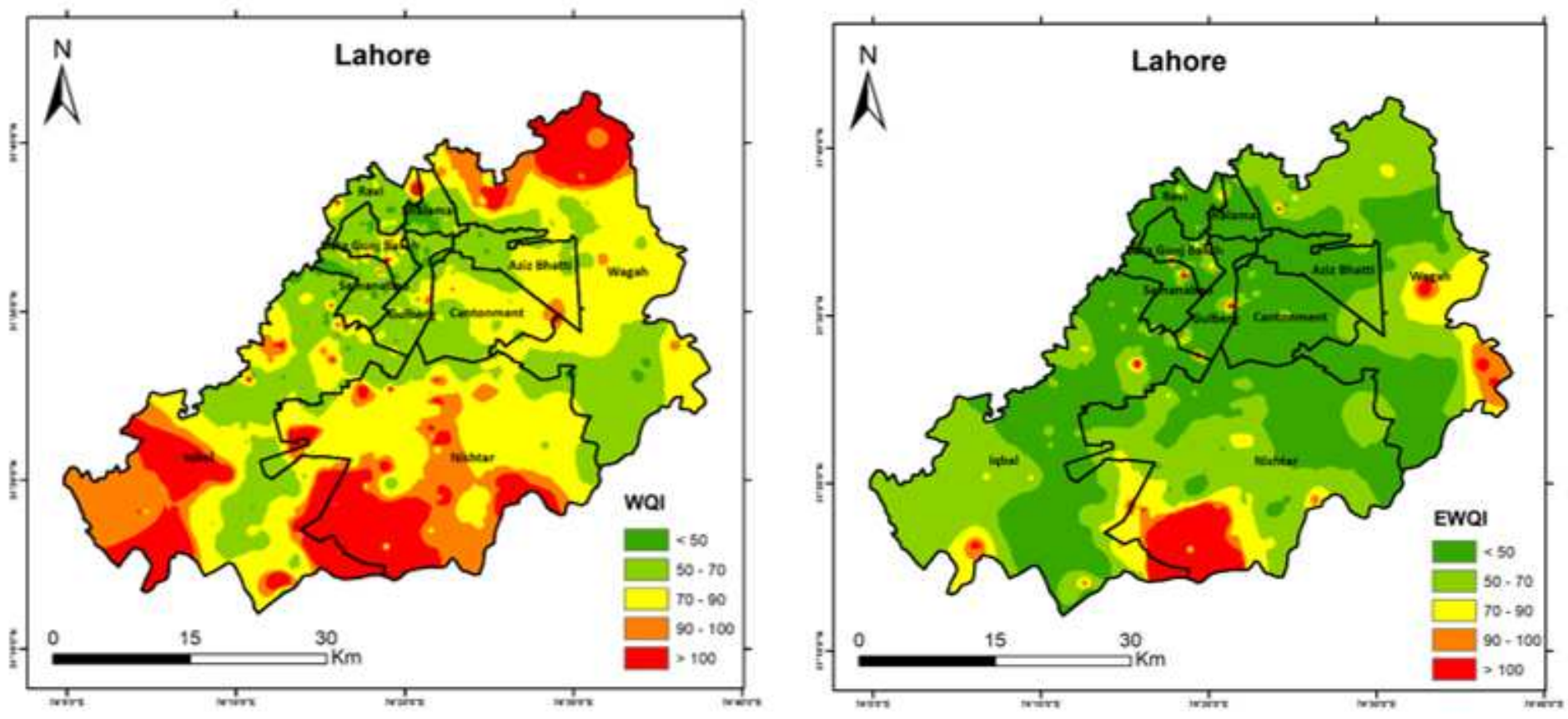

Figure 14

Summary spatial map of WQI and EWQI in the Lahore Region. Note: The designations employed and the presentation of the material on this map do not imply the expression of any opinion whatsoever on the part of Research Square concerning the legal status of any country, territory, city or area or of its authorities, or concerning the delimitation of its frontiers or boundaries. This map has been provided by the authors.
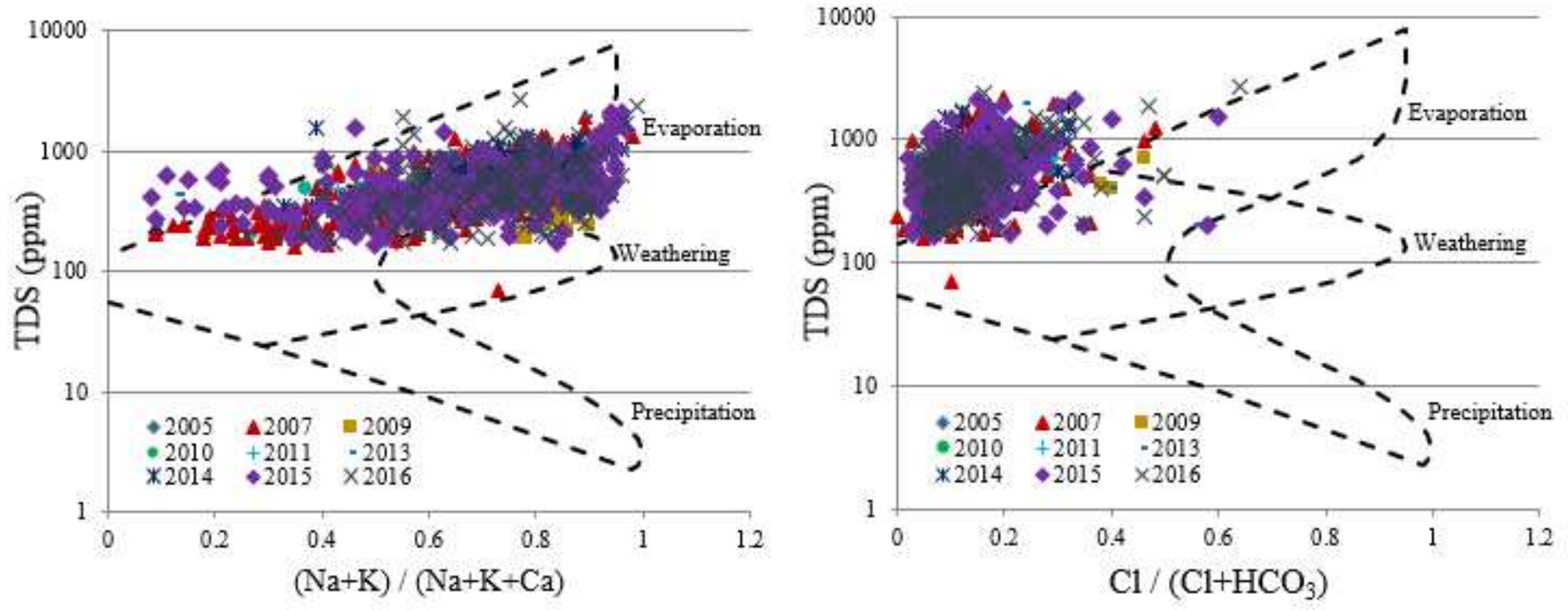

Figure 15

Gibbs plot for groundwater samples in the research area 


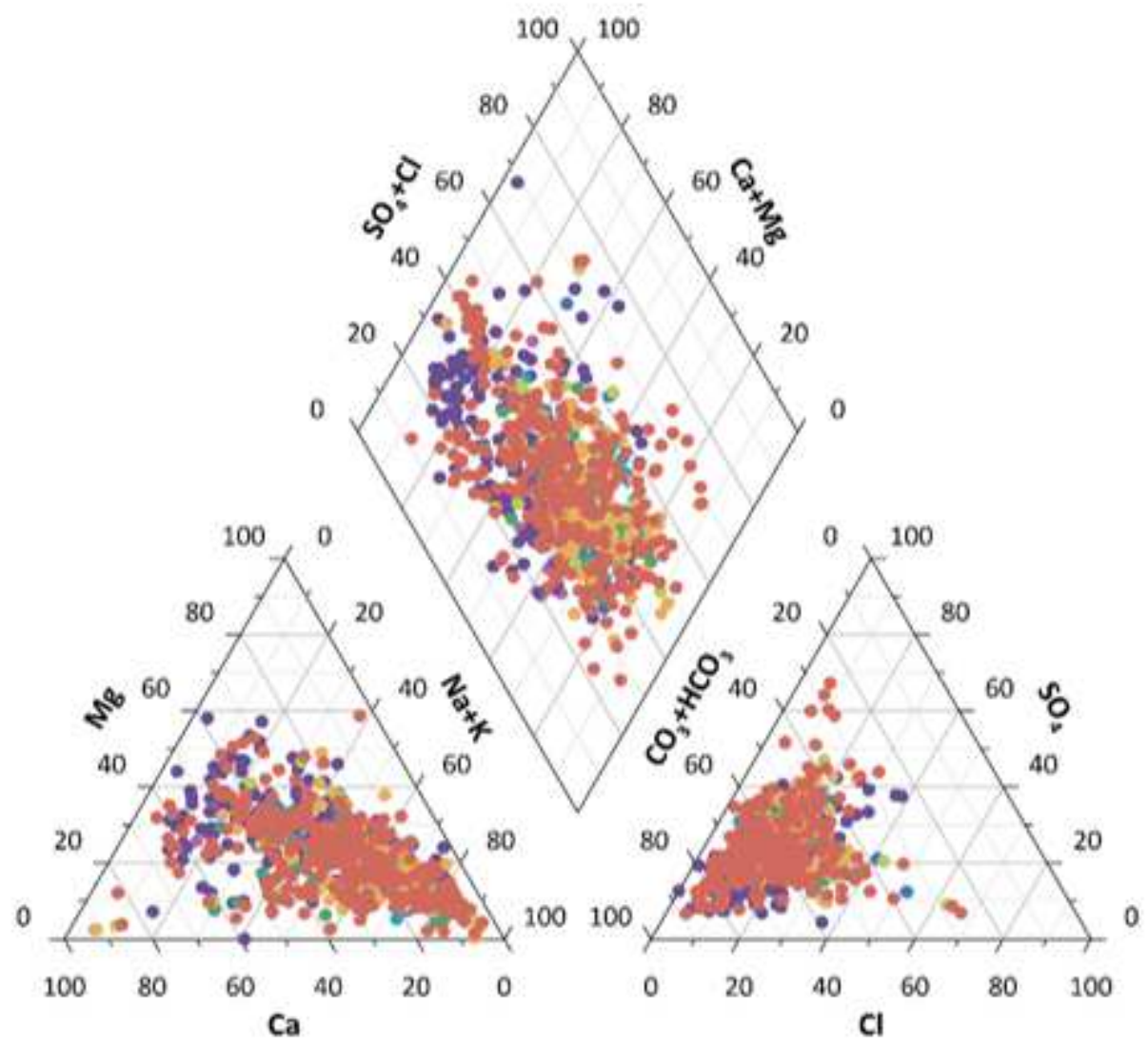

Figure 16

Piper Trilinear Diagram for groundwater samples in the research area 